\title{
Comparison of in-plane and out-of-plane needle insertion with vs. without needle guidance
}

\section{Dissertation \\ zur Erlangung des akademischen Grades}

doctor medicinae (Dr. med.)

\author{
vorgelegt dem Rat der Medizinischen Fakultät \\ der Friedrich-Schiller-Universität Jena
}

von Verena Constanze Meiser

geboren am 06.03.1989 in Schweinfurt 
Gutachter (akademischer Grad, Vor- und Nachname sowie Wirkungsort)

1. Prof. Dr. Guntinas-Lichius; Klinik für Hals, Nasen und Ohrenheilkunde Jena

2. Prof. Dr. Hans-Joachim Mentzel; Institut für Diagnostische und Interventionelle Radiologie Jena

3. Prof. Dr. Peter Jecker, Klinik für Hals, Nasen und Ohrenheilkunde Bad Salzungen

Tag der öffentlichen Verteidigung: 01.08.2017 


\section{Inhaltsverzeichnis}

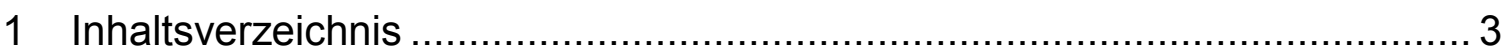

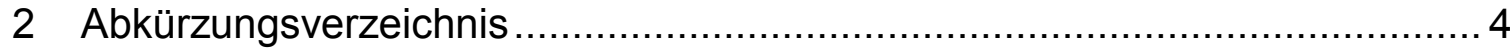

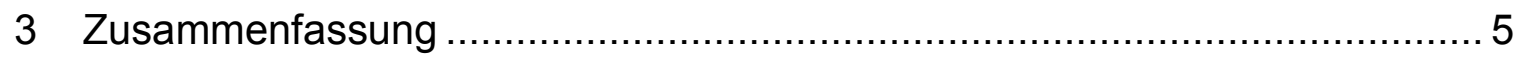

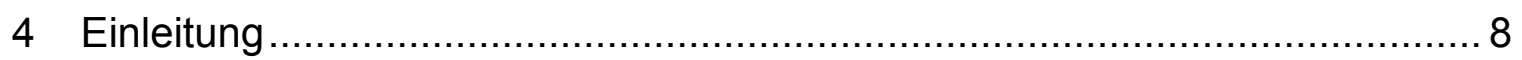

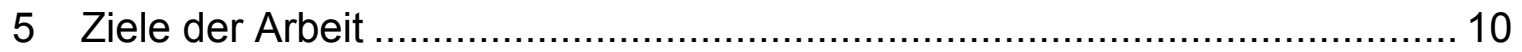

6 Comparison of in-plane and out-of-plane needle insertion with vs. without needle guidance, Meiser VC, Kreysa H, Guntinas-Lichius O, Volk GF, Eur Arch Otorhinolaryngol.; volume 273, issue 9, pp 2697-2705, 2016

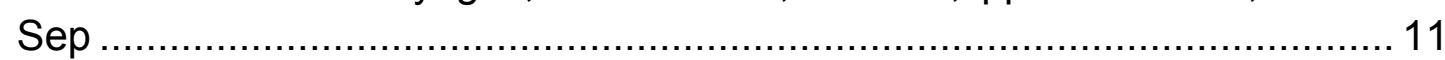

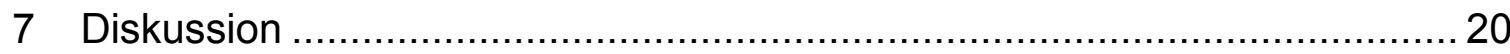

7.1 IP mit und ohne NGS im Vergleich (B3 zu B1) ............................ 20

7.2 OOP mit und ohne NGS im Vergleich (B4 zu B2) ........................ 21

7.3 IP und OOP ohne NGS (B1 zu B2) ........................................... 22

7.4 Zusammenfassung und Limitationen............................................ 23

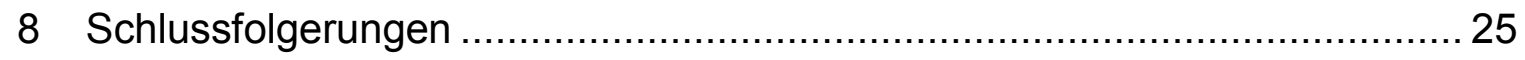

9 Literatur- und Quellenverzeichnis .................................................... 26

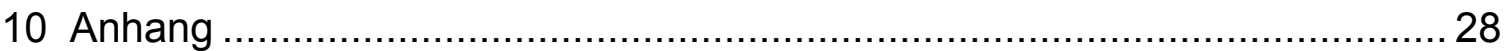

10.1 Bilder und Tabellen aus der Publikation ...................................... 28

10.2 Fragebogen zur Studie „Ultraschallgestützte Punktion an einem

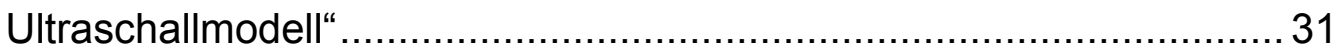

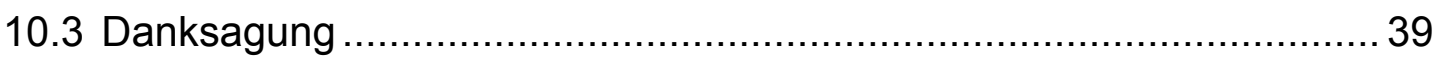

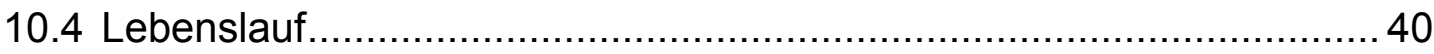

10.4.1 Persönliches: .......................................................... 40

10.4.2 Studium und Schulausbildung: ..................................... 40

10.4.3 Praktische Erfahrungen und Zusatzqualifikationen:.............. 40

10.4.4 Zusätzliche Tätigkeiten und Engagements: ....................... 41

10.4.5 Besondere Auszeichnungen: .................................... 41

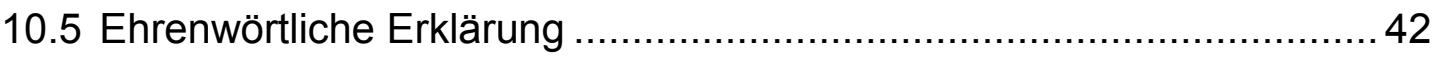


2 Abkürzungsverzeichnis 4

\section{Abkürzungsverzeichnis}

NGS needle guidance system

Nadelführungssystem

IP

in plane

OOP out of plane

In der Schallebene

Außerhalb der Schallebene 


\section{Zusammenfassung}

Ziel dieser Arbeit war es, in einem kontrollierten experimentellen Versuchsaufbau Daten zu sammeln, wie man ultraschallgestützte Punktionen im klinischen Alltag sicherer und effizienter durchführen kann. Diese Arbeit beschäftigte sich als Erste mit dem direkten Vergleich der zwei genutzten Stichtechniken bei ultraschallgestützten Punktionen: Die Nadelführung innerhalb der Schallebene (In plane: IP) wurde der Nadelführung außerhalb der Schallebene (Out of plane: OOP) gegenübergestellt und zwar jeweils mit und ohne Nutzung des Prototyps eines neu entwickelten Nadelführungssystems (Needle Guidance System: NGS). Des Weiteren wurde für diese Arbeit eine direkte visuelle Erfolgskontrolle der Nadelführung innerhalb des teilweise transparenten Ultraschall-Phantoms neu entwickelt und erfolgreich angewandt.

Als Probanden wurden punktionsunerfahrene Medizinstudenten akquiriert, um individuelle Vorerfahrungen auszuschließen und so eine möglichst allgemeingültige Empfehlung abgeben zu können, mit welcher Stichtechnik der unerfahrene Anwender schneller und vor allem präziser arbeiten kann. Die bisher erschienenen Arbeiten bieten hierzu keine zu verallgemeinernde Empfehlung, da sich ein deutlicher Bias aus Punktionserfahrung und den persönlichen Vorlieben der Anwender ergeben (Gao et al. 2016).

Die Stichtechniken wurden an einem eigens hergestellten teilweise transparenten Ultraschall-Phantom durch 24 punktionsunerfahrene Studenten angewendet. Die Nadelführung innerhalb des Phantoms konnte hierbei durch zwei Kameras aus zwei Perspektiven aufgezeichnet und diese Videos anschließend auf Zielgenauigkeit, Anzahl der Punktionsversuche, Anzahl der unbemerkten Treffer und Zeit bis zum ersten Treffer auf direktem Wege ausgewertet werden. Insgesamt hatte jeder Proband vier Versuchsbedingungen zu erfüllen. IPPunktion mit und ohne NGS sowie OOP-Punktion mit und ohne NGS. Für jede Bedingung waren 5 Minuten Zeit festgesetzt, in der der Proband so viele Punktionen auf direktem Wege durchführen sollte wie möglich. Die deskriptive Statistik wurde mit SPSS 20 berechnet. Dabei wurde der Wilcoxon-Test verwendet, um Unterschiede zwischen den Techniken und durchgeführten Studienbedingungen mit und ohne NGS zu berechnen. Als Signifikanzniveau wurde ein $p$ von 0.05 festgesetzt. 
In der OOP Stichtechnik unter Verwendung des NGS ließen sich im Vergleich zur Punktion ohne NGS signifikant mehr Treffer auf den ersten Versuch $(p<0.001)$ sowie auch insgesamt signifikant mehr Treffer in der festgelegten Zeit erzielen $(p=0.009)$. Auch war die Zeit bis zum ersten Treffer in dieser Bedingung am kürzesten. Bei OOP-Punktion ohne NGS wurden signifikant mehr unbemerkte Treffer erzielt $(p<0.001)$ als in dieser Bedingung mit NGS. Keine signifikanten Unterschiede bestanden im Vergleich der IP Stichtechnik mit und ohne NGS. Auch der direkte Vergleich der beiden Stichtechniken ohne NGS erbrachte keine signifikanten Unterschiede. Im Vergleich der beiden Stichtechniken IP und OOP mit NGS zeigte sich die Technik außerhalb der Schallebene in allen untersuchten Punkten signifikant überlegen.

Erstaunt hat das Ergebnis im Bereich der IP Punktionstechnik. Die Verwendung des NGS erbrachte bei den Probanden kein signifikant besseres Ergebnis. Dies lässt sich am ehesten damit erklären, dass die zum damaligen Zeitpunkt verwendete 3-D Darstellung des NGS keine wesentlichen Zusatzinformationen an den Anwender weitergibt. Die direkte Kontrolle der Nadelführung erfolgt bei korrekt ausgeführter Punktion bereits auf dem Ultraschallbild. Hingegen ist bei der Punktion außerhalb der Schallebene ein gutes räumliches Vorstellungsvermögen gefragt und mit der 3-D Darstellung des NGS eine bessere Orientierung auch für den unerfahrenen Anwender zu erlangen. Der Vergleich beider Techniken ohne NGS erbrachte keine signifikanten Unterschiede, da jede Technik für unerfahrene Anwender ihre eigene Schwierigkeit hat. Die Nadel exakt und vor allem auf ganzer Länge in der Schallebene zu führen erfordert visuell-motorisches Geschick, während bei der Punktion außerhalb der Schallebene überwiegend eine räumliches Vorstellungsvermögen gefragt ist. Die Tiefe des Punktionsziels ergibt den Abstand der Nadeleinstichstelle zum Schallkopf, solange die Nadel im $45^{\circ}$ Winkel vorgeschoben wird. Die klare Überlegenheit der Punktion OOP mit NGS sehen wir in den Zusatzinformationen, die dem Anwender über das NGS gegeben werden. Dies gewährleistet eine deutlich verbesserte Orientierung in Raum und Tiefe, ließ sich durch die unerfahrenen Anwender schnell erlernen und in direkte Treffer umwandeln.

Das NGS erhöht vor allem in der OOP-Technik die Treffgenauigkeit und Effektivität bei ultraschallgestützten Punktionen am Phantom. Das bedeutet für 
die klinische Anwendung Vorteile für Patient und Anwender, egal ob bei Feinnadelpunktionen, Gefäßzugängen, bei muskuloskelettalen Injektionen oder in der Regionalanästhesie. 


\section{Einleitung}

Ultraschall wird im klinischen Alltag routinemäßig genutzt und gelangt auch über die reine Diagnostik hinweg z.B. bei ultraschallgestützten Punktionen zu mehr Bedeutung. Mit dem Ultraschall steht dem Mediziner eine beinahe überall verfügbare, kostengünstige und sichere Methode zur Verfügung. Die Ultraschalltechnik wird zunehmend auch dazu genutzt, Interventionen wie Gefäßzugänge, Regionalanästhesie oder Feinnadelbiopsien sicherer und effizienter zu machen. Hierbei konnte schon gezeigt werden, dass Interventionen mit ultraschall-gestützten Systemen weniger Komplikationen mit sich bringen als konventionell nach anatomischen Landmarken durchgeführte Punktionen (Karakitsos et al. 2006, Nicolaou et al. 2007, Miller et al. 2002). Der nächste technische Schritt nach dem B-Mode Ultraschall zur Visualisierung der Nadel ist es, Nadelnavigationssysteme zu nutzen, die die Nadel unabhängig vom Ultraschallbild für den Anwender sichtbar machen. Eine dieser Methoden lokalisiert die Nadel in einem elektromagnetischen Feld. Mittlerweile gibt es bereits einige Ergebnisse der verschiedensten Navigationstechniken in Kombination mit Ultraschall, die allesamt das Handling von Ultraschall-gestützten Punktionen weiterentwickelt haben und auch mehr Patientensicherheit versprechen (Kopac et al. 2013, Ewertsen et al. 2011, Collins et al. 2013). Die nachfolgend präsentierte präklinische Studie stellt eine weitere Neuerung im Bereich der ultraschallgestützten Punktionen dar, da die Nadel beliebig frei im Raum geführt werden kann und die bildtechnische Unterstützung zu beinahe allen ultraschallgestützten Punktionen angewendet werden kann. Außer dem Ultraschallgerät werden nur der neuentwickelte Schallkopf und eine magnetisierte Punktionsnadel benötigt. Es ist kein weiteres Material wie z.B. ein Magnetsensor erforderlich, was diese Technik deutlich preiswerter und auch direkt am Patientenbett anwendbar macht. Wie in Abb1. gezeigt, wurden die IPPunktion mit und ohne NGS der OOP-Punktion mit und ohne NGS gegenübergestellt. 
4 Einleitung $\mid 9$

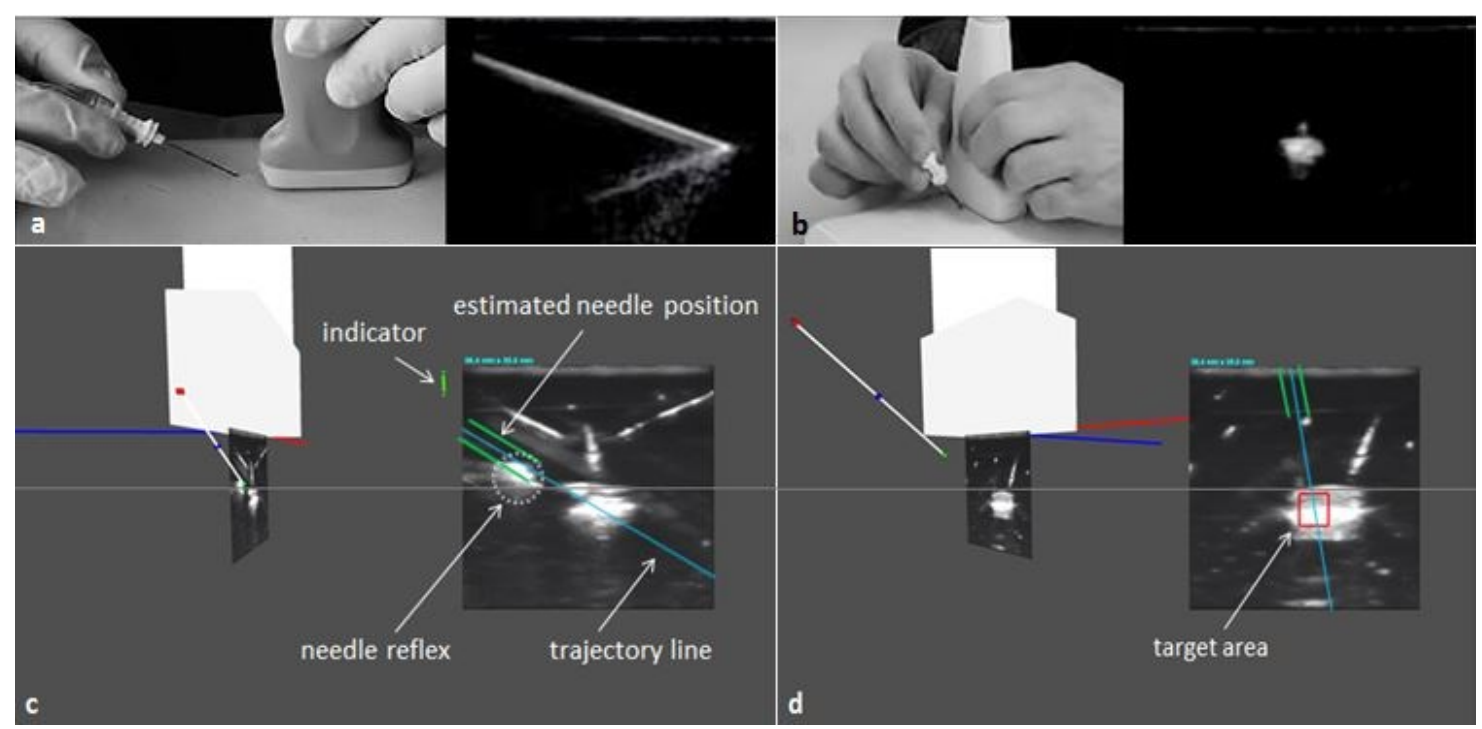

Abb. 1 Studienbedingungen: a: B1: in plane ohne NGS: Hauteinstich an der kurzen

Seite des Schallkopfes und Vorschub in der Schallebene, die Nadel ist auf ganzer Länge im B-Mode Ultraschallbild sichtbar; b: B2: out of plane ohne NGS: Hauteinstich mittig an der langen Seite des Schallkopfes und Vorschub auf die Schallebene zu, die Nadel wird als hyperechogener Punkt im B-Mode Ultraschallbild sichtbar; c: B3: in plane ohne NGS; d: B4: out of plane ohne NGS 


\section{Ziele der Arbeit}

Mit dieser präklinischen Studie werden zum Einen die zwei gängigen Stichtechniken in ihrer Anwendbarkeit und Genauigkeit analysiert, zum anderen erstmalig am Phantom der zurückgelegte Weg der Nadel zu jedem Zeitpunkt sichtbar gemacht, so dass eine genaue Auswertung der Treffer und Treffgenauigkeit aus mehreren Perspektiven erfolgen konnte. Weiterhin wurden unerfahrene Probanden rekrutiert, um eine Einschätzung geben zu können, mit welcher der Techniken auch ein ungeübter Anwender zügig und treffsicher punktieren kann. Den unerfahrenen Anwender zu analysieren ist notwendig, da auf Grund der großen Verfügbarkeit und erweiterten Anwendung ultraschallgestützter Punktionen auch zunehmend ultraschall- und punktionsunerfahrene Ärzte diese Methode am Patienten anwenden.

Diese Arbeit ist aus der Zusammenarbeit zwischen der HNO-Klinik Jena und dem Hersteller medizinischer tragbarer Ultraschallgeräte eZono AG in Jena entstanden. eZono befand sich gerade in der Neuentwicklung der Nadelführungstechnologie eZGuide $®$ und hat das Verbrauchsmaterial, die Räumlichkeiten, das Ultraschallgerät sowie die Webcams und Computer zur Aufzeichnung der Punktionsversuche zu Verfügung gestellt. Diese Studie wurde mit dem Prototypen des eZGuide ${ }^{\circledR}$ durchgeführt und hat durch Befragung der Anwender und Auswertung der beobachteten Fehler zur Weiterentwicklung der Software und Verbesserung des intuitiven Verständnis der Grafikoberfläche beigetragen.

Die enge Zusammenarbeit zwischen Industrie und Hochschulmedizin konnte so sowohl grundlegende Fragestellungen klären (Ist IP oder OOP einfacher zu erlernen?) als auch entscheidend zur Weiterentwicklung von Medizinprodukten beitragen ohne dass finanzielle Abhängigkeiten und daraus Interessenkonflikte entstanden. Die Firma hatte keinen Einfluss auf die Auswertung der Ergebnisse und die Darstellung in der Publikation. Erste Ergebnisse konnten bereits auf dem deutschen HNO-Kongress in Nürnberg 2013 präsentiert werden (Meiser et al. April 15, 2013). 


\section{Comparison of in-plane and out-of-plane needle insertion with vs. without needle guidance, Meiser VC, Kreysa $H$, Guntinas-Lichius O, Volk GF, Eur Arch Otorhinolaryngol.; volume 273, issue 9, pp 2697-2705, 2016 Sep}

\section{Comparison of in-plane and out-of-plane needle insertion with vs. without needle guidance}

Verena Constanze Meiser $^{1} \cdot$ Helene Kreysa $^{2} \cdot$ Orlando Guntinas-Lichius $^{1}$. Gerd Fabian Volk ${ }^{1}$

Received: 6 August 2015/Accepted: 15 October 2015/Published online: 23 October 2015

(c) Springer-Verlag Berlin Heidelberg 2015

\section{Abstract}

Purpose First comparison of two methods of needle insertion: long axis ("in-plane") versus short axis ("out-ofplane") approach, each with and without a prototype needle guidance system (NGS).

Materials and methods 24 medical students without prior experience punctured an ultrasound phantom (transparent except for the decklayer) in four conditions, with the goal of achieving as many accurate punctures as possible within a fixed time.

Results Out-of-plane with NGS led to substantially more hits at first attempt than punctures without NGS $(p<0.001)$, as well as to a greater total number of hits $(p=0.004)$, and participants were faster to hit the target the first time $(p=0.009)$.

Conclusions Thus, navigation increases accuracy as well as efficiency of ultrasound guided punctures on the phantom. It could prove advantageous in clinical applications for fine needle biopsies, musculoskeletal injections, vascular access, and in regional anesthesia.

Electronic supplementary material The online version of this article (doi:10.1007/s00405-015-3806-3) contains supplementary material, which is available to authorized users.

$\triangle$ Gerd Fabian Volk

fabian.volk@med.uni-jena.de

1 Department of Otorhinolaryngology, Jena University Hospital, Lessingstraße 2, 07740 Jena, Germany

2 Department of General Psychology, Friedrich Schiller University Jena, Am Steiger 3/Haus 1, 07743 Jena, Germany
Keywords Needle guidance - Fine needle biopsy - Inplane $\cdot$ Out-of-plane $\cdot$ Comparison of short and long axis . Ultrasound

\section{Introduction}

Point-of-care ultrasound is becoming more and more important in clinical routine [1]. Many interventions, such as vessel cannulations, fine needle biopsies or conductive anesthesia use ultrasound guidance to raise the safety and efficiency [2]. Several studies have demonstrated that the complication rate decreases using ultrasound-guided systems in comparison to conventional needle-insertion techniques using landmarks [2-4]. The next technological step after using B-mode ultrasound to visualize the needle is to use navigation technologies that display the needle independent of the ultrasound picture. One such method is the use of electromagnetic localization systems. Currently, first results from different systems using navigation technologies in combination with ultrasound are becoming available and promise enhanced handling of ultrasound-guided intervention, as well as improved safety for the patients [58]. Until now, systematic randomized studies examine the effect of different needle insertion methods and their interaction with the novel navigation techniques is completely missing.

The primary objective of this study was to compare two methods of needle insertion: the in-plane, or long axis approach (see Fig. 1a) and the out-of-plane, or short axis (see Fig. 1b) approach. Each approach was tested both with and without a prototype needle guidance system (see Fig. 1c, d). Additional goals of the study were to learn more about the two needle techniques and to optimize the technology. 


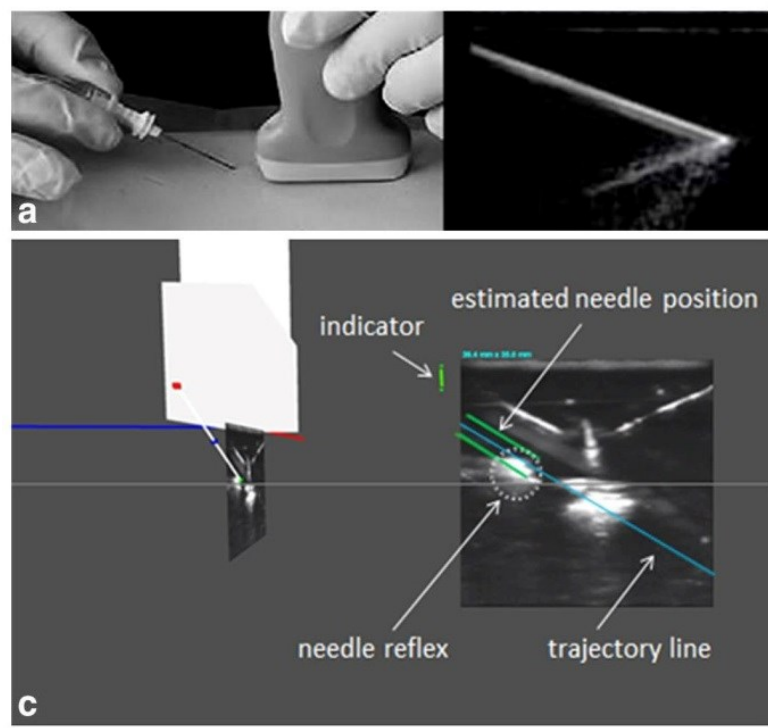

Fig. 1 Study conditions: a B1: in-plane without NGS: insertion of the needle on the short side of the probe approaching it in the ultrasound area. Complete view of the needle on the ultrasound screen; b B2: out-of-plane without NGS: centre the needle on the long

\section{Materials and methods}

\section{Participants}

Twenty-four medical students without prior experience in ultrasound-guided cannulation participated in the study. A questionnaire using a visual analog scale $(1=$ low to $10=$ high) assessed the students' previous experience with ultrasound, background knowledge, and subjective confidence in dealing with ultrasound and ultrasound-guided punctures.

\section{Needle guidance system}

This study examined a novel passive electromagnetic needle guidance system (NGS) called "eZGuide", developed by eZono AG (Jena, Germany; Fig. 1). The technology tracks any magnetized needle in the surrounding of the ultrasound transducer without using an active electromagnetic field generator. A normal disposable needle is magnetized with a permanent $\mathrm{o}$-shaped magnet provided by eZono. A 21 Gauge B Braun "Sterican” needle (Gr. 2, Ø $0.80 \times 40 \mathrm{~mm}$, green; B. Braun Melsungen AG, Melsungen, Germany) on a $10 \mathrm{ml}$ syringe (B. Braun Melsungen AG) was used with the eZono 3000 ultrasound machine (eZono AG Jena, Germany). A modified 6-12 MHZ ultrasound transducer (Samsung 8LA-SC, modified with incorporate sensors by eZono AG Jena, Germany) contains

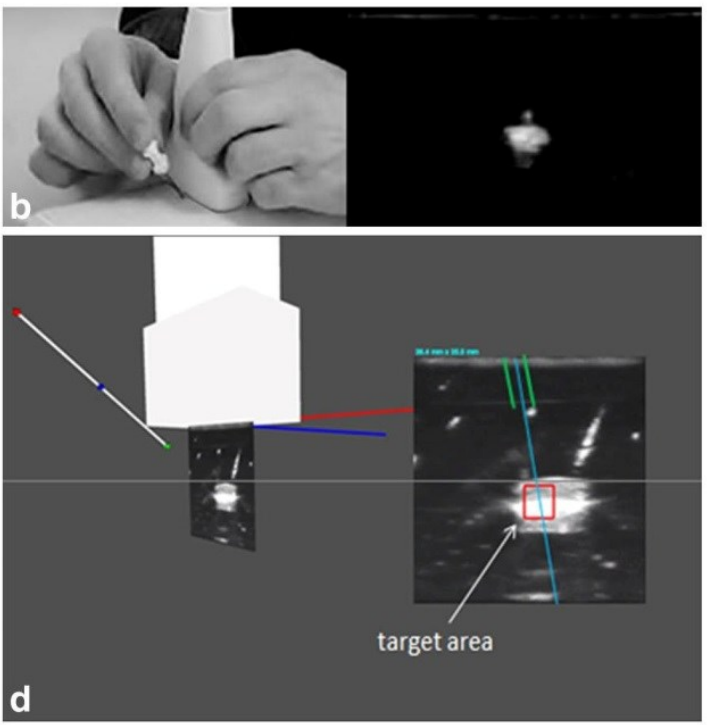

side of the probe approaching it towards the ultrasound area. The needle reaches the plane as a hyper-echoic dot on the b-mode ultrasound screen; c B3: in-plane with NGS; d B4: out-of-plane with NGS

an array of magnetic sensors completely integrated in the transducer, which detect the surrounding magnetic fields and the fields caused by the magnetized needle. No additional instruments or modifications are required, such as a separate transmitter or sensor [9], which might restrict the movement of transducer and needle. Algorithms use these measurements as input to calculate the position and orientation of the needle relative to the $2 \mathrm{D}$ ultrasound image plane. The tracking software provides a split-screen user interface: next to the usual $2 \mathrm{D}$ ultrasound screen, a 3Dmodel shows the plan of the probe, the ultrasound area and the position of the needle in relation to the ultrasound area (Fig. 1c, d). The prototype NGS, running on a separate personal computer, was switched on and off depending on the required insertion technique. The system technology was still in development stage and the graphical user interface was very basic at the time of the study (July/ August 2012), so the experiments were also performed to optimize the technology further.

\section{Phantoms}

The gel phantoms $(15 \times 10 \times 5 \mathrm{~cm})$ used for the study were transparent except for the deck layer (Fig. 2), to evaluate not only the effect of the electromagnetic needle guidance system but also two different approaches of needle insertion. The phantoms were tailor-made semitransparent gel blocks (regular liquid plastic 2228LP and 


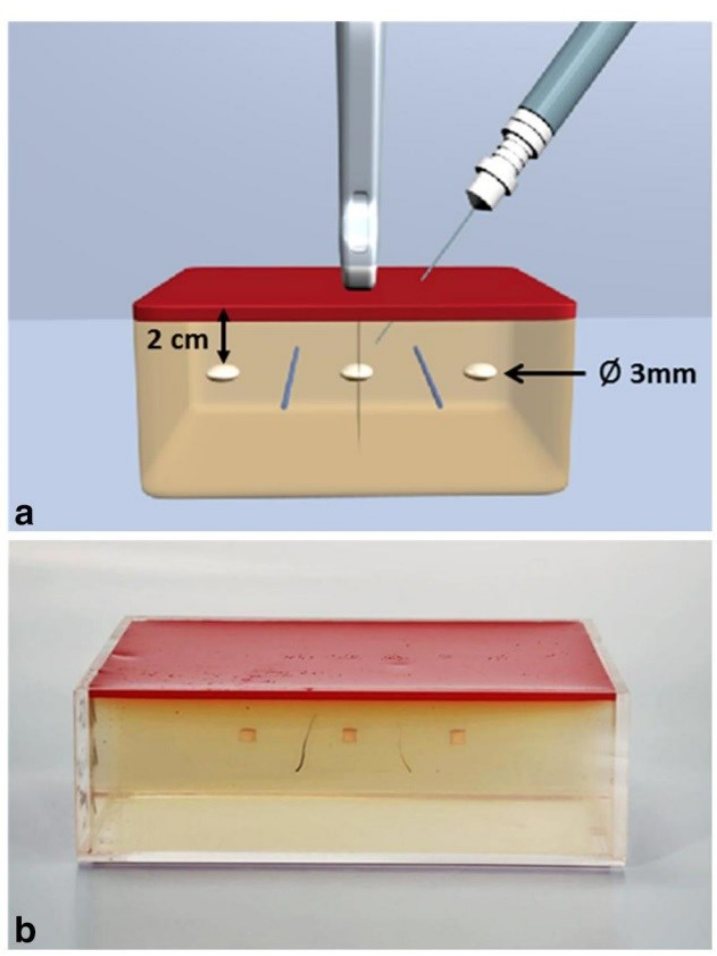

Fig. 2 Phantom; a phantom draft with three hyper echoic targets ( $\varnothing$ $3 \mathrm{~mm}$, distance $2.5 \mathrm{~cm}$ ) in $2 \mathrm{~cm}$ depth; b tailor-made transparent gel phantom with intransparent surface

plastic softener 4132S, M-F Manufacturing Company, Fort Worth, Texas 76117) with three hyper-echoic white targets (talcum powder mixed with the liquid plastic, $\varnothing 3 \mathrm{~mm}$, distance $2.5 \mathrm{~cm}$ ) placed $2 \mathrm{~cm}$ below the intransparent red surface (M-F Liquid Color 3300-16- red, M-F Manufacturing Company, Texas) of the phantom. This surface faced the participant to avoid any direct visual feedback. Each participant used one phantom for all four conditions.

\section{Performance}

Four different conditions, hereafter referred to as "blocks", were tested in pseudorandomized order: Block 1 (B1) was the in-plane technique without NGS, B2 out-of-plane technique without NGS, B3 in-plane technique with NGS, and B4 out-of-plane technique with NGS. All 24 $(4 \times 3 \times 2)$ possible sequences of the four blocks were performed once, so each student was tested in a different order. To evaluate performance, two cameras (Logitech C210, LOGITECH GmbH, Munich, Germany) were installed $10 \mathrm{~cm}$ below and $6 \mathrm{~cm}$ beside the phantom, recording the needle approaching the targets as shown in Fig. 3. A camcorder (Canon HF100, Canon GmbH,
Krefeld, Germany) in front of the work space (Fig. 4) recorded the handling of the needle and the ultrasound scanner detected the time point of each insertion of the needle.

After being screened with the questionnaire, each student received his or her own pseudorandomized order of the four different blocks. In each block, following a taskspecific introduction using Open Office Impress 3.4 the students had 5 min to perform as many successful punctures as possible. The countdown began with an auditory signal before the students placed the transducer on the phantom and ended with a second signal after $5 \mathrm{~min}$. During this time, the students were asked to indicate every hit by placing a fingertip on the syringe and saying "punction". In combination with the video recordings it was retrospectively possible to evaluate whether the hit was successful or not. Unrecognized hits were counted as negative events.

\section{In-plane technique without and with NGS}

To perform the in-plane technique (B1), students were instructed to insert the needle on the short side of the probe and approach it in the ultrasound area. This is the only technique which allows a complete view of the needle on the ultrasound screen during the whole process. Because the range of the ultrasound area is very small, it is difficult to hold the needle completely in the plane.

While performing the in-plane technique with the NGS (B3), the students received an overview of the real position of the needle relative to the ultrasound plane on a second user interface. On this interface, a real time simulation in $3 \mathrm{D}$ visualized the plan of the probe, the needle and the estimated needle trajectory. A small graphic tool, called indicator, positioned in the left corner of the usual 2D ultrasound screen displayed the probe from the top and a colored line, symbolizing the needle, moving simultaneously with the real movement of the needle. When the needle appeared in the ultrasound plane, the line became green, when it passed out of it, the line returned to red. This should help the user to place the needle exactly below the probe in the plane visualized by the ultrasound. Two parallel green lines indicated the estimated projection of the detected needle's position onto the ultrasound plane. Between these lines the hyper-echoic needle reflex was visible. Another dashed line indicated the continued needle trajectory along the longitudinal axis of the needle (Fig. 1c). If the operator advanced the needle forward from this position without tilting, the needle would follow this trajectory. The students were instructed to place and orient the needle so that the trajectory reached the target before inserting the needle into the phantom. 

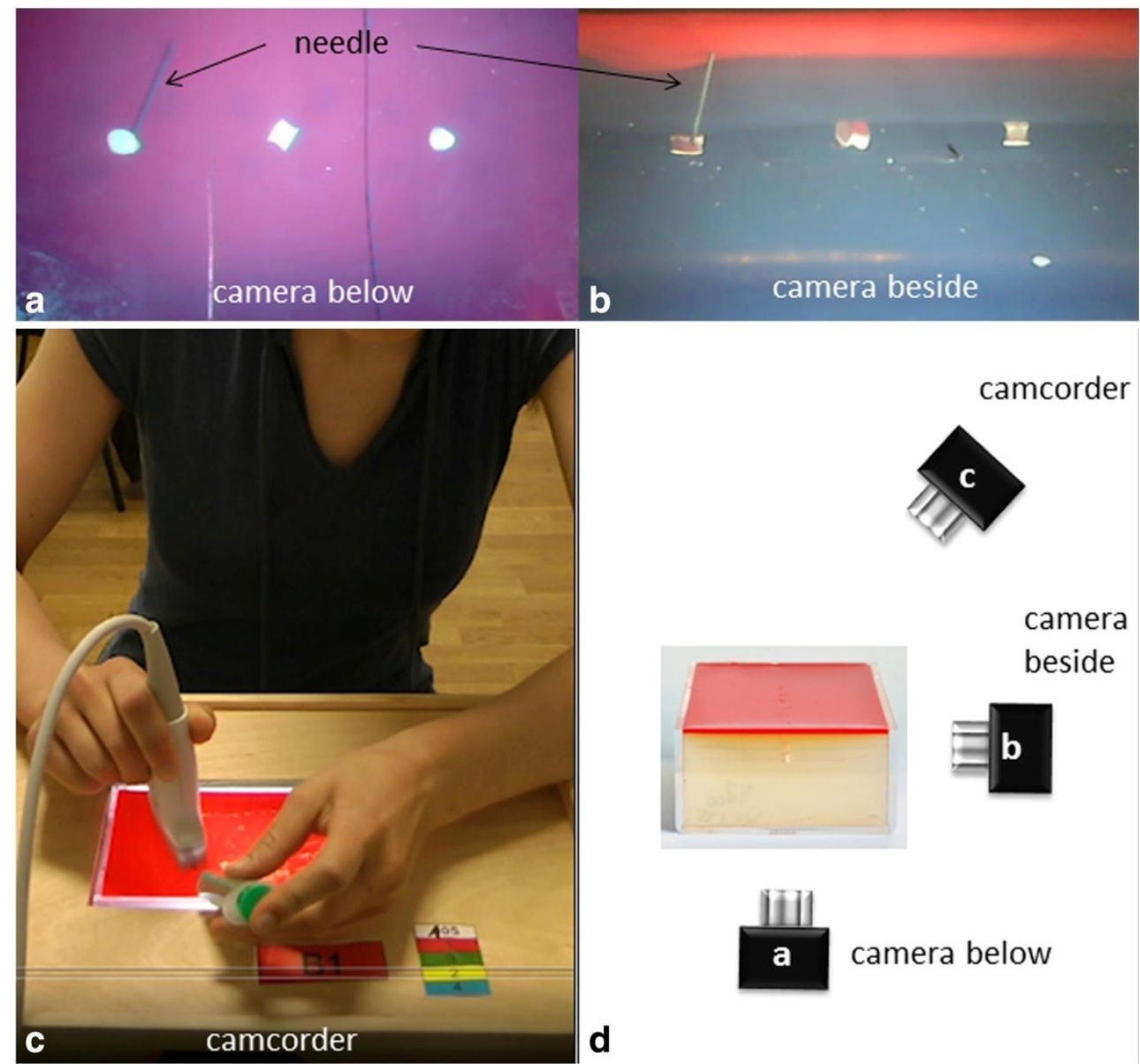

Fig. 3 Camera perspectives: a camera below the phantom; b camera beside the phantom; c camcorder in front of and above the workplace; d set-up draft of the camera positions in relation to the phantom

\section{Out-of-plane technique without and with NGS}

In contrast, for performing the out-of-plane technique (B2) the students were instructed to center the needle on the long side of the probe and approach it towards the ultrasound plane. Only if the needle reached the plane could it be seen on the b-mode ultrasound screen as a hyper-echoic dot. This technique made it especially important to position the target in the middle of the ultrasound screen. If the students detected the depth of the target from the ultrasound screen and placed the needle tip at the same distance centered on the long side of the probe to form an isosceles triangle, by inserting the needle at an angle of $45^{\circ}$, the target should be hit after $\sim 2.8 \mathrm{~cm} \mathrm{[8^{ \wedge } ( 1 /}$ 2)]. In out-of-plane technique it was difficult to differentiate whether the hyper-echoic dot visible in the b-mode was caused by the tip of the needle or by a middle section of the needle.
For performing this technique with NGS (B4), the 3D user interface differed in some details to the one in B3. Instead of the indicator in B3, B4 tested a different form of assisting tool: a colored square, called target-area. This square indicated the estimated position at which the needle tip was predicted to cross the ultrasound image plane for out-of-plane injections (Fig. 1d). Using up/down and right/left movements, the square could be moved on the $2 \mathrm{D}$ ultrasound screen until it aligned with the target. When the needle approached the ultrasound plane, the color of the square turned from red to green. When reaching the ultrasound plane, the user could also see the hyper-echoic dot of the needle on the ultrasound screen. If the square was exactly positioned before inserting the needle, the needle should hit the target (see also the instructions in the supplementary material). 


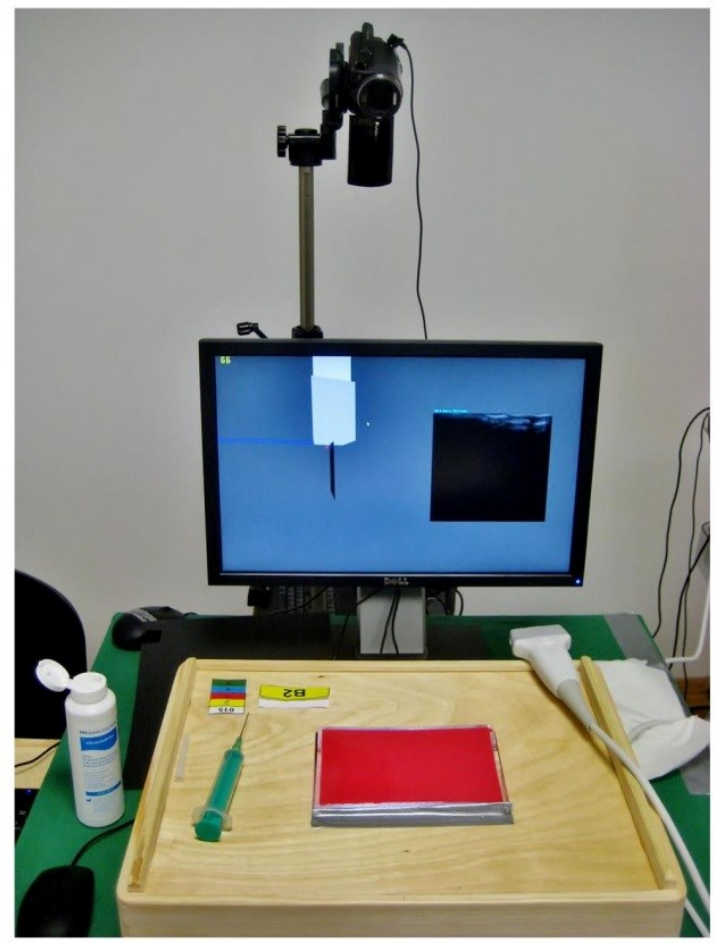

Fig. 4 Work space: the setting from the participant's point of view with the monitor and camcorder above, the phantom and two webcams inside a wooden box, the needle and gel on the left, transducer and ultrasound scanner on the right

\section{Objectives}

The objectives of this study were to detect the number of first attempt hits in $5 \mathrm{~min}$, the time needed to hit the target the first time, the number of unrecognized hits and the number of total recognized hits in the 5 min measuring period. We defined the number of first attempt hits in 5 mins as hits which participants made by inserting the needle directly, without any redirection or retraction. The total recognized hits were defined as the total number of hits on target correctly indicated by the participant in every 5-min time period. An unrecognized hit was defined as a hit confirmed by the camera but without being recognized or indicated by the participant saying "punction". The time to hit the target the first time was measured from the beginning of the 5-min time period until the first recognized hit.

\section{Statistics}

Descriptive statistics were calculated using the statistical software package SPSS 20 (IBM SPSS 20.0 for Windows, SPSS Inc., Chicago, IL., USA). Tests for normal distribution were performed using the Shapiro-Wilk test of normality for small sample sizes. The Wilcoxon sign test for non-parametric repeated measures was then used to evaluate the differences between techniques and between the blocks performed with and without NGS. Comparisons between groups were made by Student's $t$ test. The significance level was set at 0.05 .

\section{Results}

As assessed in the initial questionnaire, participants' experience of working with any ultrasound prior to the study was extremely limited $(3.5 \pm 3.91 \mathrm{~h})$, as was their confidence at using ultrasound $(3.1 \pm 1.53)$ on a visual analog scale, with $1=$ feeling unsure, $10=$ feeling safe. Previous experience with ultrasound-guided cannulations or punctures was an exclusion criterion.

\section{Comparing in-plane with and without NGS (B3 to $\mathbf{B 1}$ )}

No consistent effect of the NGS was found for in-plane punctures, although the NGS (B3) resulted in a slightly higher number of first attempt hits $(2.6 \pm 2.5$ hits $)$ than punctures without NGS (B1: $2.4 \pm 2.6$ hits; $p=0.740$ ). The time to hit the target the first time increased from an average of $80 \pm 87 \mathrm{~s}$ in B1 to $89 \pm 74 \mathrm{~s}(p=0.771)$ in B3. The number of total hits was actually somewhat higher without NGS $(5.0 \pm 2.9$ hits $)$ than with guidance ( $4.1 \pm 2.3$ hits; $p=0.221$ ), though this was also true for the number of unrecognized hits (B1: $2.5 \pm 2.4$ hits; B3: $1.6 \pm 3.0$ hits; $p=0.052$ ), but all these results failed to reach statistical significance (Table 1).

\section{Comparing out-of-plane with and without NGS (B4} to $\mathbf{B 2}$ )

However, the value of the NGS showed up clearly for outof-plane punctures: here, the NGS (B4) led to a significantly higher number of first attempt hits $(5.4 \pm 3.1$ hits $)$ in comparison to punctures without NGS (B2: $1.5 \pm 2.0$ hits; $p<0.001)$. Similarly, less time was needed to hit the target the first time (B4: $31 \pm 27 \mathrm{~s} ; \quad \mathrm{B} 2: 81 \pm 89 \mathrm{~s}$;

Table 1 Results: in plane conditions without (B1) and with (B3) NGS

\begin{tabular}{lcc}
\hline Objectives & B1 without NGS & B3 with NGS \\
\hline Number of first attempt hits & $2.4 \pm 2.6$ & $2.6 \pm 2.5$ \\
Time to hit the first target (s) & $80 \pm 87$ & $89 \pm 74$ \\
Number of all recognized hits & $5.0 \pm 2.9$ & $4.1 \pm 2.3$ \\
Number of unrecognized hits & $2.5 \pm 2.4$ & $1.6 \pm 3.0$ \\
\hline
\end{tabular}

Data are presented as mean \pm SD 
Table 2 Results: out of plane conditions without (B2) and with (B4) NGS

\begin{tabular}{lcc}
\hline Objectives & B2 without NGS & B4 with NGS \\
\hline Number of first attempt hits & $1.5 \pm 2.0^{*}$ & $5.4 \pm 3.1$ \\
Time to hit the first target (s) & $81 \pm 89^{*}$ & $31 \pm 27$ \\
Number of all recognized hits & $5.0 \pm 2.9^{*}$ & $7.0 \pm 2.8$ \\
Number of unrecognized hits & $4.0 \pm 3.3^{*}$ & $0.8 \pm 1.0$
\end{tabular}

Data are presented as mean $\pm \mathrm{SD}$

$* p<0.05$

$p=0.009$ ), and the total number of hits in 5 mins was higher (B4: $7.0 \pm 2.8$ hits; B2: $5.0 \pm 2.9$ hits; $p=0.004$ ). The number of unrecognized hits was much higher without guidance $(4.0 \pm 3.3$ hits $)$ than with NGS $(0.8 \pm 1.0$ hits; $p<0.001$ ) (Table 2).

Comparing in-plane and out-of-plane without NGS (B1 to B2)

The facilitatory effects of the NGS on out-of-plane but not in-plane punctures are particularly striking in view of the fact that performance in the absence of a guidance system is comparable for the two techniques: No significant differences were found without NGS between in-plane (B1) and out-of-plane cannulations (B2). This is true for the number of first attempt hits (B1: $2.4 \pm 2.6$ hits; B2: $1.5 \pm 2.0$ hits; $p=0.934$ ); the time to hit the target the first time (B1: $80 \pm 87 \mathrm{~s} ; \mathrm{B} 2: 81 \pm 89 \mathrm{~s} ; p=0.726$ ), and the total number of hits in $5 \mathrm{~min}-5.0$ hits in both conditions (B1: $5.0 \pm 2.9$ hits; B2: $5.0 \pm 3.0$ hits; $p=0.596$ ).

Comparing in-plane and out-of-plane with NGS (B3 to $\mathbf{B} 4)$

In contrast, comparing the two techniques with NGS (B3, B4) resulted in significant differences on all measures: outof-plane technique with NGS (B4) led to a much higher number of first attempt hits $(5.4 \pm 3.1$ hits $)$ than in-plane technique with NGS (B3: $2.6 \pm 2.5$ hits; $p<0.001$ ), as well as shorter time to first hit the target (B3: $89 \pm 74 \mathrm{~s}$; B4: $31 \pm 27 \mathrm{~s} ; p=0.001)$, and a greater number of total hits in 5 mins (B4: $7.0 \pm 2.8$ hits; B3: $4.1 \pm 2.3$ hits; $p<0.001)$. The results are summarized in Fig. 5 .



Fig. 5 Diagram of the results; first attempt hits, unrecognized hits and total recognized hits refer to the left $y$-axis ("hits in 5 min"); time displays the four conditions: $B 1$ in-plane without NGS, $B 2$ out-ofto hit the target refers to the right $y$-axis ("time in $\mathrm{s}$ "); the $x$-axis 


\section{Discussion}

The design of the study allowed a comparison of "inplane" and "out-of-plane" needle insertion techniques. Additionally, this study compared NGS-equipped ultrasound with conventional ultrasound for ultrasound-guided punctures by novice medical students.

\section{Comparing in-plane with and without NGS (B3 to B1)}

There was no statistical difference between the results of in-plane punctures with and without NGS. This could be due to the limited additional information that the NGS provides in this condition.

Nevertheless, several important observations were made. First, it seemed challenging for the unexperienced participants to reevaluate the needle position continuously on the interface and translate it into the correct movements required to direct the needle to the target. Second, there was only a very small range of perfect alignment for which a green indicator was shown on the $2 \mathrm{D}$ ultrasound screen (implying that the needle is correctly aligned). Third, the user interface was very abstract and not obvious to users.

Based on these observations, we were able to suggest certain improvements to the user interface and the NGS technology, which have since been implemented by eZono.

A study by Matt Levine et al. [10] using the improved visualization of the needle alignment function seem to assist trainees to develop their ability to align the needle with the ultrasound beam during in-plane ultrasound guided nerve blocks.

More generally, we would like to point out the importance of providing hands-on training with NGS systems on phantoms before their use on patients. Such opportunities for familiarization with the system would likely achieve better results. Interestingly, although the comparison of the number of unrecognized hits between the two in-plane conditions was not significant, this number tended to be lower using the NGS. This is a very relevant safety issue: not to realize that a vessel or even the posterior wall has been penetrated can be very dangerous for the patient. The NGS may help to reduce this risk. Perhaps the combination of a NGS with an echo-enhanced needle as Crum et al. [11] describe it in their work could affect the problem of posterior wall penetration in a positive way.

\section{Comparing out-of-plane with and without NGS (B4 to $\mathbf{B 2}$ )}

For out-of-plane cannulation, use of the NGS (B4) resulted in a much higher number of first attempt hits than cannulations without NGS (B2). In addition, less time was needed to hit the target the first time, and the number of total hits in 5 mins was higher. Importantly, unrecognized hits were much more frequent without NGS. Thus, the NGS is a big advantage for novices, especially in the outof-plane modus. Shi et al. [12] describe similar results with untrained anesthetists performing a simulated nerve block on phantoms in out-of-plane technique with and without a navigation system. In another recently published study, Auyong et al. [13] were able to use the improved commercial version of the NGS (eZono 4000 with eZGuide) to show considerably improved needle accuracy and cannulation time during simulated internal jugular vein puncture by physicians with ultrasound experience. A verification of all these preclinical observations in a clinical study is still outstanding. According to Brinkmann et al. [14], the benefit of a needle guidance system seems to be maximized for out-of-plane approaches because the system extrapolates where the needle tip will intersect the ultrasound plane based on the needle trajectory. This allows for unlimited needle entry starting points along the long edge of the transducer with a shorter needle approach. The needle trajectory does not need to line up with the plane of the ultrasound beam as necessary for in-plane approaches and, therefore, this constraint is eliminated. Brinkmann et al. [14] analyzed a case report by Wong et al. [15] with ultrasound-guided spinal anesthesia using the electromagnetic based Ultrasonix GPS needle tracking system. Using an electromagnetic based NGS, the lack of real needle visibility is compensated by the technical and graphical support. Not only for fine needle biopsies of suspicious neck tumors of thyroid nodes but also for vessel cannulations, spinal anesthesia and many other procedures this system would be very useful to visualize where the needle tip is at all times during the procedure. Even if the visualization of adjacent structures in the short axis is sometimes more important, scanning the area before performing the cannulation is necessary independent of the use of a NGS. Technology cannot and should not replace anatomic understanding and strategy, but it may positively influence the needle advancement by providing greater confidence of hitting the target. This would serve to minimize the risk of perforation of the posterior vessel wall as shown in a study by Moon et al. [16]. It was not the aim of the present study to examine this special case, but a further study using this system on patients is in progress.

\section{Comparing in-plane and out-of-plane without NGS (B1 to B2)}

In our study, the time to hit the target the first time showed no difference between the two techniques. The total number of hits also did not differ between the two techniques, though the number of first attempt hits in five minutes was 
slightly, though not significantly, higher in-plane than outof-plane.

Blaivas et al. [17] also compared the short-axis with long-axis approaches to vascular access and found that novice sonographers successfully completed the procedure in less time when using the short-axis approach. Berk et al. [18] reported that arterial cannulation by in-plane approach increased the rate of catheter insertion success at the first attempt compared to out-of-plane approach. The cannulation time was in the study of Berk et al. [18] shorter in an in-plane group compared to an out-of-plane group. But these results are based on an in vivo study with two experienced anesthetists who had placed more than 50 arterial lines using both insertion techniques. Mahler et al. [19] reported that the short-axis technique required less insertion time than the long-axis technique. The success rate was higher in the short-axis group, but this difference was not statistically significant. The number of needle sticks, total procedure time, patient satisfaction scores, and the complication rate did not significantly differ between the two different groups. To the best of our knowledge there are only a few studies that have compared different needle techniques during ultrasound guided arterial cannulation [20]. Most of them compare the two techniques on vascular access.

All in all, for novices no clear difference was detectable in performing the two techniques. Considering that these results are based on punctures of very small targets $(\varnothing 3 \mathrm{~mm})$ in reproducible clear designed phantoms, we can pronounce no clear recommendation regarding which technique should be performed. It depends on the user's experience and preferences which technique is promising. In fact, novice users, as the students of this study, found it nearly impossible to achieve a hit at the first attempt in the out-of-plane technique. To assess the depth of the target and to estimate the distance at which to insert the needle requires a good three-dimensional imagination. It could be helpful to imagine an isosceles triangle with the needle trajectory being the hypotenuse and the depth of the target and distance between needle and transducer the two isosceles sides. It is also helpful to position the target in the middle of the ultrasound screen and then insert the needle with high precision in the same plane. The perpendicular plane crossing the ultrasound probe in its midline is perhaps the most intuitive configuration, but in the end a successful puncture without NGS-whether in-plane or out-of-plane- depends on the personal experience, the likes and dislikes.

\section{Summary and limitations}

Although this study was based on a limited number of students, it nevertheless led to significant findings. The pseudorandomization served to counteract learning effects as shown by the fact that across all participants the same number of total hits were made in the first and the last series. Together with the comparable prior experience of the participants, this should increase also the reliability of the results. Furthermore, the study lays the groundwork for future research. Our evaluation enabled us to make well-founded suggestions on how to develop the tracking system further. Studies like this, testing how usable and "foolproof" novel techniques are, are essential for developing manageable and save devices. In our case, the improved visualization with the new system could be expected to show an even greater benefit of the NGS [13]. Evaluating how novice users react using this novel technique of needle guidance was one of the main objectives of our study. Of course, due caution is required when generalizing these findings based on an abstract gel model to real patients. However, the results show that even novices with no prior training obtained better results with the NGS than without it. It is plausible that the NGS may fill the gap of inexperience with visualized information about the needle approach, making it particularly useful in the practical training of novices on phantoms and subsequently on real patients. The encouraging results by Auyong et al. [13] suggest that similar benefits can be found for experienced users. The tailor-made gel model simulating a needle access to a small round target was developed for this first study with the system to use cameras in addition to the ultrasound machine to evaluate the accuracy of the needle guidance. It was necessary to use semi-transparent gel to visualize the needle approach in the phantom and at the same time to avoid all visual feedback for the participants. Gelatin or custom-made models did not meet all of these requirements. Choosing very small targets raised the requirement to work in a very exact and considered way. Simulating a real vascular access including bigger vessels and a bigger range to puncture it was not the main emphasis, because the NGS offers many more opportunities. The fact that it does not require a specially modified needle, extra sensors or field generators, provides a considerable advantage in many clinical applications.

\section{Conclusion}

Especially in out-of-plane technique, the needle guidance system increased the accuracy as well as the efficiency of ultrasound-guided cannulations on the phantom without optical access to the target. This technology promises important advances in the clinical workflow [21] not only for needle biopsies but probably also for vascular access, musculoskeletal injections and in regional anesthesia. 
Compliance with ethical standards

Funding The Company eZono AG Jena (Spitzweidenweg 30, D-07743 Jena, Germany) provided the ultrasound scanner with the prototype needle guidance system for the time the trial was running. No further funding was secured for this study.

Conflict of interest eZono provided a prototype of the ultrasound machine for the time of the study and was otherwise not involved in study design, execution, and analysis. VCM has received a travel grant from the German Society of Oto-Rhino-Laryngology, Head and Neck Surgery to present parts of this study on the 84th annual meeting 2013 in Nürnberg, Germany. GFV has received a research grant from the Interdisziplinäres Zentrum für Klinische Forschung (IZKF) of the Jena University Hospital, Jena, Germany.

\section{References}

1. Moore CL, Copel JA (2011) Point-of-care ultrasonography. New Engl J Med 364(8):749-757. doi:10.1056/NEJMra0909487

2. Nicolaou S, Talsky A, Khashoggi K, Venu V (2007) Ultrasoundguided interventional radiology in critical care. Crit Care Med 35(5 Suppl):S186-S197. doi:10.1097/01.CCM.0000260630. 68855.DF

3. Karakitsos D, Labropoulos N, De Groot E, Patrianakos AP, Kouraklis G, Poularas J, Samonis G, Tsoutsos DA, Konstadoulakis MM, Karabinis A (2006) Real-time ultrasound-guided catheterisation of the internal jugular vein: a prospective comparison with the landmark technique in critical care patients. Crit Care 10(6):R162. doi:10.1186/cc5101

4. Miller AH, Roth BA, Mills TJ, Woody JR, Longmoor CE, Foste B (2002) Ultrasound guidance versus the landmark technique for the placement of central venous catheters in the emergency department. Acad Emerg Med Off J Soc Acad Emerg Med 9(8):800-805

5. Kopac DS, Chen J, Tang R, Sawka A, Vaghadia H (2013) Comparison of a novel real-time SonixGPS needle-tracking ultrasound technique with traditional ultrasound for vascular access in a phantom gel model. J Vasc Surg 58(3):735-741. doi:10.1016/j.jvs.2013.03.007

6. Ewertsen C, Nielsen KR, Nielsen MB (2011) Freehand biopsy guided by electromagnetic needle tracking: a phantom study. Ultraschall Med 32(6):614-618. doi:10.1055/s-0031-1281852

7. Collins GB, Fanou EM, Young J, Bhogal P (2013) A comparison of free-hand vs laser-guided long-axis ultrasound techniques in novice users. Br J Radiol 86(1029):20130026. doi:10.1259/bjr. 20130026

8. Wallach D, Toporek G, Weber S, Bale R, Widmann G (2013) Comparison of freehand-navigated and aiming device-navigated targeting of liver lesions. The international journal of medical robotics+computer assisted surgery MRCAS. doi:10.1002/res. 1505

9. Hakime A, Deschamps F, De Carvalho EG, Barah A, Auperin A, De Baere T (2012) Electromagnetic-tracked biopsy under ultrasound guidance: preliminary results. Cardiovasc Intervent Radiol 35(4):898-905. doi:10.1007/s00270-011-0278-8
10. Levine DM LM, Gadsden J (2014) Training with on-screen needle-probe alignment cues improves skill acquisition in novice trainees performing ultrasound-guided nerve blocks. Abstract Presented at the 39th Annual Regional Anesthesiology and Acute Pain Meeting, Chicago, IL, 3-6 April 2014

11. Crum T, Adhikari S, Lander L, Blaivas M (2014) Do echo-enhanced needles make a difference in sonographically guided vascular access? J Ultrasound Med Off J Am Inst Ultrasound Med 33(4):623-628. doi:10.7863/ultra.33.4.623

12. Shi J, Schwaiger J, Lueth TC (2011) Nerve block using a navigation system and ultrasound imaging for regional anesthesia. Conf Proc Annu Int Conf IEEE Eng Med Biol Soc IEEE Eng Med Biol Soc Conf 2011:1153-1156. doi:10.1109/IEMBS.2011. 6090270

13. Auyong DB, Yuan SC, Rymer AN, Green CL, Hanson NA (2015) A randomized crossover study comparing a novel needle guidance technology for simulated internal jugular vein cannulation. Anesthesiology 123(3):535-541. doi:10.1097/ALN 0000000000000759

14. Brinkmann S, Vaghadia H, Sawka A, Tang R (2013) Methodological considerations of ultrasound-guided spinal anesthesia using the Ultrasonix GPS needle tracking system. Can J Anaesth J Canadien d'anesthesie 60(4):407-408. doi:10.1007/s12630013-9884-z

15. Wong SW, Niazi AU, Chin KJ, Chan VW (2013) Real-time ultrasound-guided spinal anesthesia using the SonixGPS(R) needle tracking system: a case report. Can J Anaesth J Canadien d'anesthesie 60(1):50-53. doi:10.1007/ s12630-012-9809-2

16. Moon CH, Blehar D, Shear MA, Uyehara P, Gaspari RJ, Arnold J, Cukor J (2010) Incidence of posterior vessel wall puncture during ultrasound-guided vessel cannulation in a simulated model. Acad Emerg Med Off J Soc Acad Emerg Med 17(10):1138-1141

17. Blaivas M, Brannam L, Fernandez E (2003) Short-axis versus long-axis approaches for teaching ultrasound-guided vascula access on a new inanimate model. Acad Emerg Med Off J Soc Acad Emerg Med 10(12):1307-1311

18. Berk D, Gurkan Y, Kus A, Ulugol H, Solak M, Toker K (2013) Ultrasound-guided radial arterial cannulation: long axis/in-plane versus short axis/out-of-plane approaches? J Clin Monit Comput 27(3):319-324. doi:10.1007/s10877-013-9437-6

19. Mahler SA, Wang H, Lester C, Skinner J, Arnold TC, Conrad SA (2011) Short- vs long-axis approach to ultrasound-guided peripheral intravenous access: a prospective randomized study. Am J Emerg Med 29(9):1194-1197. doi:10.1016/j.ajem.2010.07. 015

20. Shiloh AL, Savel RH, Paulin LM, Eisen LA (2011) Ultrasoundguided catheterization of the radial artery: a systematic review and meta-analysis of randomized controlled trials. Ches 139(3):524-529. doi:10.1378/chest.10-0919

21. Gadsden J, Latmore M, Levine DM (2015) Evaluation of the eZono 4000 with eZGuide for ultrasound-guided procedures. Expert Rev Med Devices 12(3):251-261. doi:10.1586/17434440. 2015.995095 


\section{Diskussion}

Das Design der Studie lässt einen Vergleich der zwei Stichtechniken IP und OOP zu. Zusätzlich wird die Nutzung eines Nadelführungssystems während ultraschallgestützter Punktionen mit der konventionellen ultraschallgestützten Punktion vergleichen.

\subsection{IP mit und ohne NGS im Vergleich (B3 zu B1)}

Es zeigte sich kein statistischer Unterschied zwischen den Ergebnissen der IP Punktion mit und ohne NGS. Das könnte dadurch bedingt sein, dass das NGS nur begrenzt zusätzliche Information für den Anwender liefert. Bei korrekter Anwendung der Methode sieht man die gesamte Nadel und ihren Verlauf bereits im üblichen Ultraschallbild.

Nichtsdestotrotz konnten weitere wichtige Beobachtungen gemacht werden. Zu allererst schien es für die unerfahrenen Probanden eine Herausforderung zu sein die durch das NGS visualisierte Nadelposition in die richtigen Bewegungen zu übersetzen, um die Nadel zum Ziel zu führen. Weiterhin ist der Spielraum bei dem der Indikator auf dem 2D Ultraschallbild grün angezeigt wird sehr begrenzt (was dafür steht, dass die Nadel auf ganzer Länge in der Schallebene geführt wird). Auch war die bildliche Darstellung der Position im Raum anfangs sehr abstrakt und nicht selbsterklärend für den Benutzer. Anhand dieser Beobachtungen konnten wichtige Anpassungen der graphischen Darstellung und der NGS Technologie vorgenommen werden, die von eZono in der Weiterentwicklung des Prototyps umgesetzt wurden. In einer Studie von Matt Levine et al. (Levine DM 2014) wurde bereits die verbesserte Version des NGS genutzt. Dort konnte gezeigt werden, dass das NGS die Fähigkeit fördert, die Nadel korrekt während ultraschallgestützter Nervenblockaden in der IP Technik in der Ultraschallebene zu führen.

Grundsätzlich kommt dem "hands-on“ Training mit Nadelführungssystemen am Phantom eine sehr große Bedeutung vor der Anwendung am Patientenbett zu. Die Möglichkeit sich vorher mit dem System vertraut zu machen würde sicherlich noch bessere Ergebnisse erzielen, war hier aber bewusst nicht gewünscht war. Interessanterweise zeigte sich die Zahl der unbemerkten Treffer bei der Punktion mit dem NGS tendenziell niedriger, obwohl es keinen statistisch signifikanten 
Unterschied zwischen den beiden IP Stichtechniken gab. Diese Tatsache birgt einen relevanten Sicherheitsaspekt: Nicht zu realisieren, dass ein Gefäß oder dessen hintere Wand bereits penetriert wurde kann für den Patienten gefährlich werden. Das NGS kann dieses Risiko minimieren. Möglicherweise könnte die Kombination aus NGS und einer Nadel mit verstärkter Echogenität wie es Crum et al. (Crum et al. 2014) in ihrer Arbeit beschreiben die Komplikationsrate, die sich aus dem Durchstehen eines Gefäßes ergibt, positiv beeinflussen.

\subsection{OOP mit und ohne NGS im Vergleich (B4 zu B2)}

Bei der OOP Technik wurden mit NGS (B4) eine deutlich höhere Anzahl direkter Treffer erzielt als im Vergleich zu Punktionen ohne NGS (B2). Weiterhin verkürzte sich die Zeit bis zum ersten Treffer deutlich und ebenso war die Gesamtzahl der Treffer innerhalb der vorgegebenen fünf Minuten signifikant höher. Die Anzahl unbemerkter Treffer war ohne NGS wesentlich höher. Dies zeigt, dass das NGS gerade für unerfahrene Anwender und vor allem in der OOP Technik große Vorteile bringt. Shi et al. (Shi et al. 2011) beschrieben sehr ähnliche Resultate mit ungeübten Anästhesisten, die am Phantom eine simulierte Nervenblockade in der OOP Technik jeweils mit und ohne Navigation durchführten. In einer anderen kürzlich veröffentlichten Studie haben Auyong et al. (Auyong et al. 2015) bereits die weiterentwickelte Version des NGS von eZono (eZono 4000 mit eZGuide) genutzt und konnten zeigen, dass sich die Treffgenauigkeit und Punktionszeit von ultraschallerfahrenen Ärzten bei am Phantom simulierten Jugularvenenpunktionen deutlich verkürzen ließ. Die Bestätigung all dieser präklinischen Ergebnisse in einer klinischen Studie steht allerdings noch aus. Laut Brinkmann et al. (Brinkmann et al. 2013) scheint sich der positive Nutzen eines NGS gerade in OOP Techniken zu maximieren, da das System durch die graphische Darstellung des Nadelverlaufs den Eintritt der Nadel in die Schallebene genau extrapolieren kann. Diese Tatsache macht es dem Anwender möglich entlang der langen Seite des Schallkopfes den Hauteintrittspunkt gänzlich frei zu wählen, wodurch man das Ziel auf kürzest möglichem Weg erreichen kann. Der graphisch angezeigte geschätzte Nadelverlauf muss auch nicht zwingend in der Schallebene liegen wie das bei IP Punktionen zwingend notwendig ist. Brinkmann et al. (Brinkmann et al. 2013) 
haben weiterhin einen Fallbericht von Wong et al. (Wong et al. 2013) über ultraschallgestützte Spinalanästhesie in Verwendung eines auf Elektromagnetik basierenden NGS (Ultrasonix GPS) analysiert. Bei der Nutzung eines elektromagnetischen NGS wird die fehlende Nadelsichtbarkeit durch technische und graphische Unterstützung kompensiert. Das verwendete NGS ist nicht nur für Feinnadelbiopsien aus tumorverdächtigen Knoten im Kopf-Halsbereich sondern auch bei Gefäßzugängen, Spinalanästhesien oder anderen Prozeduren zur Visualisierung der Nadelspitze während des Punktionsvorganges hilfreich. Die Darstellung der angrenzenden Strukturen ist gerade in der OOP Technik wegen der fehlenden Sichtbarkeit des Nadelverlaufes von besonderer Bedeutung. Aus diesem Grund muss die Umgebung vor Punktion genau gescannt werden und zwar unabhängig von der Nutzung eines NGS. Der technische Fortschritt kann und sollte in keinem Fall ein anatomisches Verständnis und die genaue Punktionsplanung ersetzen, kann aber den Nadelvorschub durch Vermittlung von visualisierten Zusatzinformationen positiv beeinflussen. Den positiven Einfluss konnte eine Studie von Moon et al. (Moon et al. 2010) in Bezug auf die Minimierung des Risikos die Gefäßwand rückseitig zu durchstechen aufzeigen. Es war nicht Ziel der vorliegenden Studie diese spezielle Komplikation zu untersuchen. Eine klinische Studie, die das hier vorgestellte NGS bei Gefäßzugängen nutzt, ist derzeit in Arbeit.

\subsection{IP und OOP ohne NGS (B1 zu B2)}

Zwischen den zwei Techniken konnte kein Unterschied gezeigt werden, was die Zeit bis zum ersten Treffer angeht. Ebenso unterschied sich die Gesamtzahl der Treffer nicht, auch wenn die Zahl der direkten Treffer bei Nutzung der IP Technik zwar nicht signifikant, aber doch etwas höher lag als bei Nutzung der OOP Technik.

Blaivas et al. (Blaivas et al. 2003) haben bei Gefäßzugängen ebenfalls IP mit OOP verglichen mit dem Ergebnis, dass Ultraschallanfänger die Punktion IP in kürzerer Zeit erfolgreich durchführen. Berk et al. (Berk et al. 2013) konnten zeigen, dass bei IP durchgeführten Arterienzugängen die Rate der auf Anhieb erfolgreichen Katheter-Einlagen höher lag, als bei Zugängen in OOP Technik. Die Zeit, die bis zum korrekten Einführen der Kanüle benötigt wurde, war in der 
IP Gruppe kürzer als OOP. Diese Ergebnisse basieren aber auf einer klinischen Studie mit zwei erfahrenen Anästhesisten, die vorher bereits mehr als 50 Arterienkatheter in jeder der beiden Techniken gelegt hatten. Mahler et al. (Mahler et al. 2011) beschrieb, dass die IP Technik weniger Zeit zum Platzieren der Nadel in Anspruch nehme als die OOP Technik. Auch war die Erfolgsquote IP höher, dies jedoch nicht signifikant. Die Zahl der Hauteinstiche, die Gesamtdauer der Prozedur, ein Zufriedenheits-Score der Patienten und die Komplikationsrate unterschieden sich zwischen beiden Gruppen ebenfalls nicht signifikant. Unseren Recherchen zufolge gibt es nur wenige Studien, die die beiden Stichtechniken ultraschallgestützt bei arteriellen Zugängen verglichen haben (Shiloh et al. 2011). Die meisten gesichteten Arbeiten Vergleichen die zwei Techniken bei Gefäßzugängen.

Insgesamt konnte für unerfahrene Probanden kein Unterschied in der Durchführung beider Techniken aufgezeigt werden. Wenn man bedenkt, dass die gezeigten Resultate auf der Punktion von sehr kleinen Zielen ( $\varnothing 3 \mathrm{~mm}$ ) in reproduzierbaren Phantomen mit klarer Formgebung basieren, konnte keine richtungsweisende Empfehlung gegeben werden, welche Technik eher genutzt werden sollte. Tatsache ist, dass es für unerfahrene Anwender beinahe unmöglich ist in der OOP Technik das Ziel auf den ersten Versuch zu treffen. Die Tiefe des Zieles einzuschätzen und daraus den nötigen Abstand der Hauteinstichstelle zum Ultraschallkopf zu ermessen verlangt ein ausgeprägtes dreidimensionales Vorstellungsvermögen. Hilfreich kann hierbei die Vorstellung eines gleichschenkligen Dreiecks sein, bei dem die Hypotenuse der geschätzte Nadelverlauf ist und die Tiefe des Zieles sowie der Abstand zum Schallkopf die beiden gleichschenkligen Seiten sind. Eine Senkrechte, die den Schallkopf mittig schneidet, ist wahrscheinlich die intuitivste Konfiguration. Letztendendes hängt eine erfolgreiche Punktion egal ob mit oder ohne NGS jedoch von der persönlichen Erfahrung und den Vorlieben des Anwenders ab.

\subsection{Zusammenfassung und Limitationen}

Auch wenn die Studie nur eine geringe Anzahl an Probanden nutzte, konnten durch das Studiendesign und die Effektstärke der untersuchten Bedingungen einige signifikante Beobachtungen gemacht werden. Durch die 
pseudorandomisierte Reihenfolge der einzelnen Punktionsbedingungen konnte der Einfluss von Lerneffekten auf die Ergebnisse vermieden werden, was sich dadurch zeigte, dass sich die Gesamtzahl der Treffer in der ersten und letzten Punktionsbedingung bei allen Probanden nicht unterschied. Zusammen mit der Vergleichbarkeit in Bezug auf den Novizen-Status bei einheitlich fehlender Punktionserfahrung der Probanden sollte sich so die Reliabilität der Ergebnisse erhöhen. Außerdem wurden mit dieser Arbeit methodisch Grundlagen für weitere Untersuchungen gelegt. Die Beobachtungen erlaubten es fundierte Vorschläge zu machen, wie das NGS weiterentwickelt werden kann. Studien wie diese, die prüfen, inwiefern eine neue Technologie brauchbar und für den Anwender intuitiv zu nutzen ist, sind essentiell zur Entwicklung neuer und sicherer Geräte. In diesem speziellen Fall konnte die verbesserte graphische Darstellung im weiterentwickelten eZGuide einen noch eindeutigeren Zusatznutzen des NGS zeigen (Auyong et al. 2015). Zu evaluieren, wie unerfahrene Probanden im Umgang mit der neuen Technik reagieren, war ein Hauptanliegen dieser Arbeit. Natürlich ist gewisse Vorsicht geboten die hier gezeigten Beobachtungen, die auf einem abstrakten Gelphantom beruhen, direkt auf die Anwendung am Patienten zu übertragen. Nichtsdestotrotz konnte gezeigt werden, dass Probanden ohne Punktions- und Ultraschallerfahrung mit der neuen Technik ohne vorheriges Training bessere Ergebnisse mit der Verwendung des NGS erzielten als ohne. Möglicherweise kann das NGS durch den sichtbar werdenden Nadelverlauf einen Teil der Lücke füllen, den die Unerfahrenheit mit sich bringt. Das NGS bietet für unerfahrene Anwender die Möglichkeit initial im Rahmen eines Simulationstrainings am Phantom den Umgang zu erlernen und diese Erfahrung auf die Nutzung am Patienten zu übertragen. Die ermutigenden Ergebnisse von Auyong et al. (Auyong et al. 2015) deuten sogar darauf hin, dass ähnliche positive Effekte auch bei erfahrenen Anwendern zu erwarten sind. Das verwendete Ultraschallphantom, mit dem die Punktion eines sehr kleinen Ziels simuliert wurde, wurde eigens für diese Studie entwickelt. Die Transparenz machte es möglich den Nadelverlauf zusätzlich zum Ultraschallbild mit zwei Kameras zu verfolgen und so eine Aussage bezüglich der Treffgenauigkeit des NGS zu tätigen. Um den Probanden das visuelle Feedback zu nehmen, musste die Deckschicht des Phantoms undurchsichtig sein. Viele der frei käuflichen Phantome oder Gelatinemodelle erfüllten diese Anforderungen nicht. Die Ziele 
wurden bewusst so klein gewählt, um eine möglichst exakte und wohl überlegte Ausführung der Punktion zu erreichen. Einen direkten Gefäßzugang zu simulieren hätte durch die Notwendigkeit des entsprechenden Gefäß-lumens einen größeren Trefferspielraum zugelassen und wurde auf Grund der vielfältigen Nutzbarkeit des NGS bewusst nicht gewählt. Die Tatsache, dass für dieses System weder eine spezielle Nadel, noch extra Sensoren, Führungshilfen oder anderes Equipment notwendig sind verspricht einen erheblichen Vorteil für viele klinische Anwendungen.

\section{Schlussfolgerungen}

Das NGS erhöht besonders in der OOP Technik die Treffgenauigkeit und Effizienz von ultraschallgestützten Punktionen am Phantom, dessen Ziele für den Probanden von außen nicht sichtbar sind. Diese Technologie verspricht deutliche Vorteile im medizinischen Arbeitsablauf (Gadsden et al. 2015) nicht nur bei Feinnadelbiopsien, sondern ebenso bei Gefäßzugängen, muskuloskelettalen Injektionen und in der Regionalanästhesie. 


\section{Literatur- und Quellenverzeichnis}

Auyong DB, Yuan SC, Rymer AN, Green CL, Hanson NA. 2015. A Randomized Crossover Study Comparing a Novel Needle Guidance Technology for Simulated Internal Jugular Vein Cannulation. Anesthesiology, 123 (3):535541.

Berk D, Gurkan Y, Kus A, Ulugol H, Solak M, Toker K. 2013. Ultrasound-guided radial arterial cannulation: long axis/in-plane versus short axis/out-of-plane approaches? J Clin Monit Comput, 27 (3):319-324.

Blaivas M, Brannam L, Fernandez E. 2003. Short-axis versus long-axis approaches for teaching ultrasound-guided vascular access on a new inanimate model. Acad Emerg Med, 10 (12):1307-1311.

Brinkmann S, Vaghadia H, Sawka A, Tang R. 2013. Methodological considerations of ultrasound-guided spinal anesthesia using the Ultrasonix GPS needle tracking system. Can J Anaesth, 60 (4):407-408.

Collins GB, Fanou EM, Young J, Bhogal P. 2013. A comparison of free-hand vs laser-guided long-axis ultrasound techniques in novice users. Br J Radiol, 86 (1029):20130026.

Crum T, Adhikari S, Lander L, Blaivas M. 2014. Do echo-enhanced needles make a difference in sonographically guided vascular access? J Ultrasound Med, 33 (4):623-628.

Ewertsen C, Nielsen KR, Nielsen MB. 2011. Freehand biopsy guided by electromagnetic needle tracking: a phantom study. Ultraschall Med, 32 (6):614-618.

Gadsden J, Latmore M, Levine DM. 2015. Evaluation of the eZono 4000 with eZGuide for ultrasound-guided procedures. Expert Rev Med Devices, 12 (3):251-261.

Gao YB, Yan JH, Ma JM, Liu XN, Dong JY, Sun F, Tang LW, Li J. 2016. Effects of long axis in-plane vs short axis out-of-plane techniques during ultrasound-guided vascular access. Am J Emerg Med, 34 (5):778-783.

Karakitsos D, Labropoulos N, De Groot E, Patrianakos AP, Kouraklis G, Poularas J, Samonis G, Tsoutsos DA, Konstadoulakis MM, Karabinis A. 2006. Realtime ultrasound-guided catheterisation of the internal jugular vein: a prospective comparison with the landmark technique in critical care patients. Crit Care, 10 (6):R162.

Kopac DS, Chen J, Tang R, Sawka A, Vaghadia H. 2013. Comparison of a novel real-time SonixGPS needle-tracking ultrasound technique with traditional ultrasound for vascular access in a phantom gel model. J Vasc Surg, 58 (3):735-741.

Levine DM LM, Gadsden J. 2014. Training with on-screen needle-probe alignment cues improves skill acquisition in novice trainees performing ultrasound-guided nerve blocks. [Poster].

Mahler SA, Wang H, Lester C, Skinner J, Arnold TC, Conrad SA. 2011. Short- vs long-axis approach to ultrasound-guided peripheral intravenous access: a prospective randomized study. Am J Emerg Med, 29 (9):1194-1197. 
Meiser VC, Kreysa H, Guntinas-Lichius O, Volk GF. April 15, 2013. Navigation erhöht die Sicherheit und Effizienz sonographie-gestützter Punktionen: eine präklinische Studie. Nürnberg: 84. Jahresversammlung der Deutschen Gesellschaft für Hals-Nasen-Ohren-Heilkunde, Kopf- und HalsChirurgie e. V.

Miller AH, Roth BA, Mills TJ, Woody JR, Longmoor CE, Foster B. 2002. Ultrasound guidance versus the landmark technique for the placement of central venous catheters in the emergency department. Acad Emerg Med, 9 (8):800-805.

Moon CH, Blehar D, Shear MA, Uyehara P, Gaspari RJ, Arnold J, Cukor J. 2010. Incidence of posterior vessel wall puncture during ultrasound-guided vessel cannulation in a simulated model. Acad Emerg Med, 17 (10):11381141.

Nicolaou S, Talsky A, Khashoggi K, Venu V. 2007. Ultrasound-guided interventional radiology in critical care. Crit Care Med, 35 (5 Suppl):S186197.

Shi J, Schwaiger J, Lueth TC. 2011. Nerve block using a navigation system and ultrasound imaging for regional anesthesia. Conf Proc IEEE Eng Med Biol Soc, 2011:1153-1156.

Shiloh AL, Savel RH, Paulin LM, Eisen LA. 2011. Ultrasound-guided catheterization of the radial artery: a systematic review and meta-analysis of randomized controlled trials. Chest, 139 (3):524-529.

Wong SW, Niazi AU, Chin KJ, Chan VW. 2013. Real-time ultrasound-guided spinal anesthesia using the SonixGPS(R) needle tracking system: a case report. Can J Anaesth, 60 (1):50-53. 


\section{Anhang}

\subsection{Bilder und Tabellen aus der Publikation}

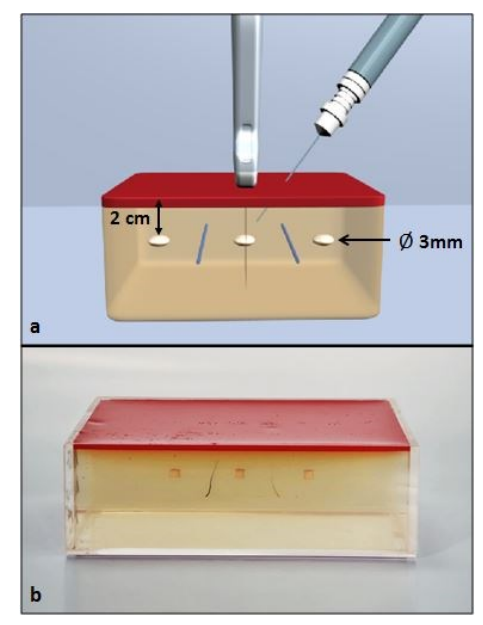

Fig. 2 Phantom; a: Phantom draft with three hyper echoic targets $(\varnothing 3 \mathrm{~mm}$, distance $2.5 \mathrm{~cm}$ ) in $2 \mathrm{~cm}$ depth; b: tailor-made transparent gel phantom with intransparent surface

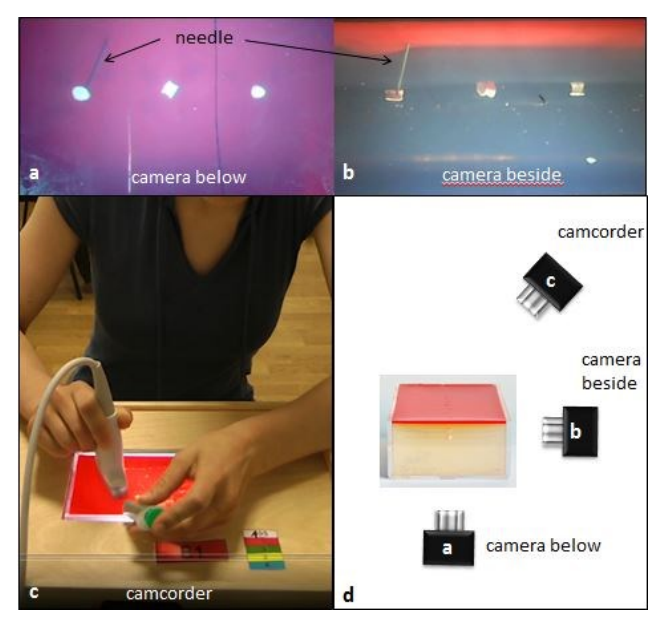

Fig: 3 Camera perspectives; a: Camera below the phantom; b: Camera beside the phantom; c: Camcorder in front of and above the workplace; d: Set- up draft of the camera positions in relation to the phantom 


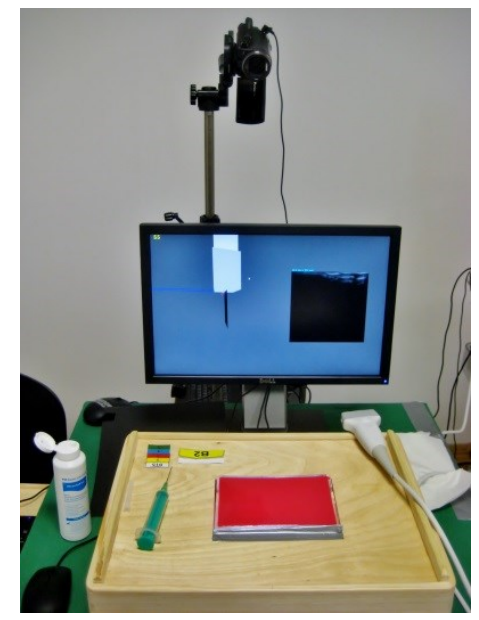

Fig. 4 Work space: The setting from the participant's point of view with the monitor and camcorder above, the phantom and two webcams inside a wooden box, the needle and gel on the left, transducer and ultrasound scanner on the right

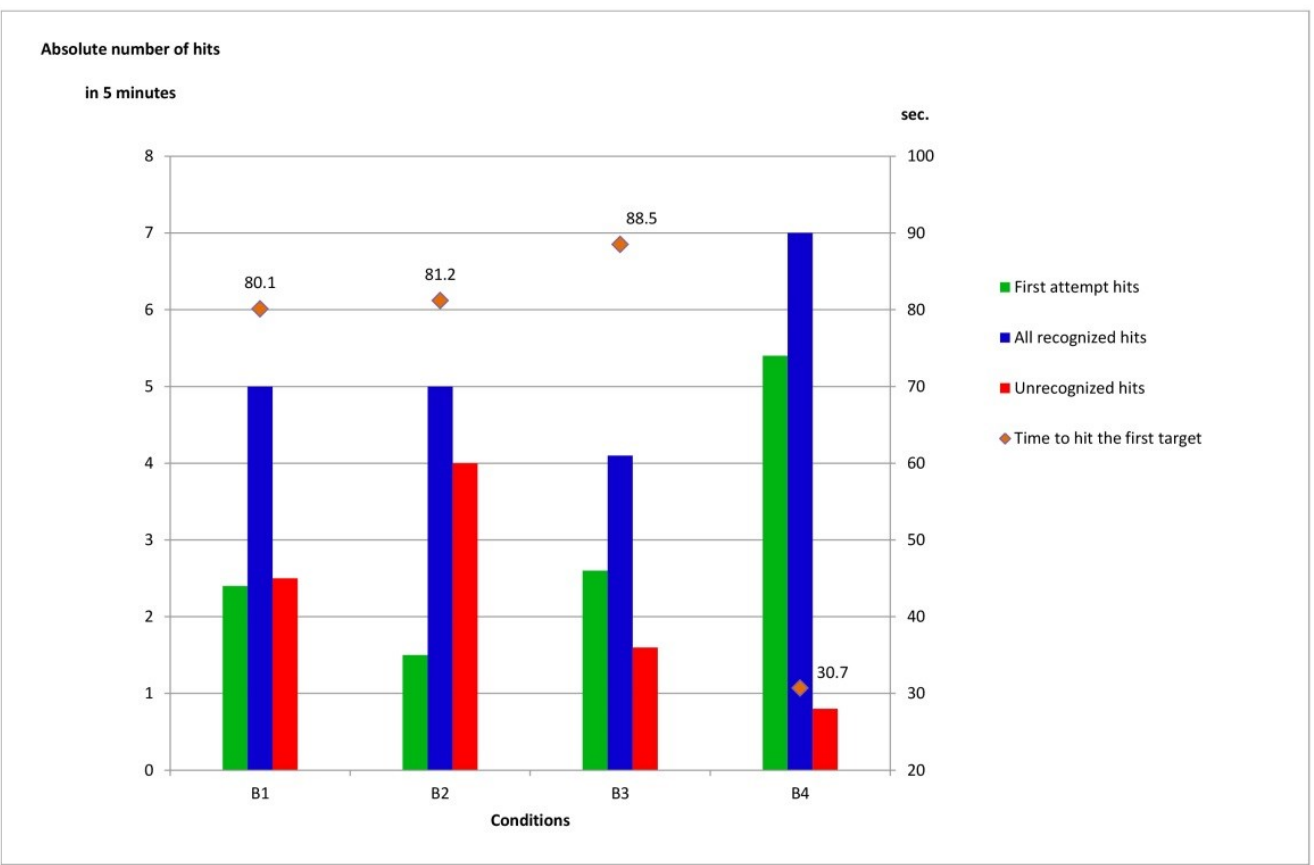

Fig. 5 Diagram of the results; first attempt hits, unrecognized hits and total recognized hits refer to the left y-axis ("hits in $5 \mathrm{~min}$ "); time to hit the target refers to the right $y$-axis ("Time in s"); the x-axis displays the four conditions: B1: in plane without NGS, B2: out of plane without NGS, B3: in plane with NGS, B4: out of plane with NGS 


\begin{tabular}{lcc}
\hline \multicolumn{1}{c}{ Objectives } & \multicolumn{1}{c}{ B1 } & \multicolumn{1}{c}{ B3 } \\
without NGS & with NGS \\
\hline number of first attempt hits & $2.4 \pm 2.6$ & $2.6 \pm 2.5$ \\
time to hit the first target (sec) & $80 \pm 87$ & $89 \pm 74$ \\
number of all recognized hits & $5.0 \pm 2.9$ & $4.1 \pm 2.3$ \\
number of unrecognized hits & $2.5 \pm 2.4$ & $1.6 \pm 3.0$ \\
\hline Tab. 1: Results: In plane conditions without (B1) and with (B3) NGS; & \\
\multicolumn{1}{c}{ data are presented as Mean \pm SD } & \\
\multicolumn{1}{c}{ Objectives } & & \\
& & B2 \\
without NGS & with NGS \\
\hline number of first attempt hits & $1.5 \pm 2.0^{a}$ & $5.4 \pm 3.1$ \\
time to hit the first target (sec) & $81 \pm 89^{a}$ & $31 \pm 27$ \\
number of all recognized hits & $5.0 \pm 2.9^{a}$ & $7.0 \pm 2.8$ \\
number of unrecognized hits & $4.0 \pm 3.3^{a}$ & $0.8 \pm 1.0$ \\
\hline
\end{tabular}

Tab. 2: Results: Out of plane conditions without (B2) and with (B4) NGS; data are presented as Mean $\pm \mathrm{SD} ;{ }^{a} \mathrm{p}<0.05$ 


\subsection{Fragebogen zur Studie „Ultraschallgestützte Punktion an einem} Ultraschallmodell“"

Teilnehmernummer Semester Alter

\section{Bitte vor dem Experiment ausfüllen:}

1 Wie sicher fühlen Sie sich im Allgemeinen Umgang mit Ultraschall?

sehr unsicher
\begin{tabular}{|l|l|l|l|l|l|l|l|l|l|}
\hline 1 & 2 & 3 & 4 & 5 & 6 & 7 & 8 & 9 & 10 \\
\hline
\end{tabular}

2 Wie sicher fühlen Sie sich in ultraschallgestützten Punktionen?

sehr unsicher
\begin{tabular}{|l|l|l|l|l|l|l|l|l|l|}
\hline 1 & 2 & 3 & 4 & 5 & 6 & 7 & 8 & 9 & 10 \\
\hline
\end{tabular}

3 Wie viele Stunden haben Sie ungefähr schon mit Ultraschall gearbeitet?

4 Wo haben Sie schon Ultraschallerfahrung gesammelt? (Mehrfachnennungen möglich)

$\square$ Vorlesung

$\square$ Seminar (Kleingruppen, ohne praktische Übungen)

$\square$ Praktikum (Kleingruppen, mit praktischen Übungen)

$\square$ Famulatur (praktische Einzelbetreuung), Fachabteilung

$\square$ andere:

5 Haben Sie schon bei ultraschallgestützten Punktionen zugesehen?

$\square \mathrm{Ja}$

Nein 
6 Haben Sie schon bei ultraschallgestützten Punktionen assistiert?

$\square \mathrm{Ja}$

$\square$ Nein

7 Haben Sie selbst schon ultraschallgestützt eine Raumforderung punktiert, einen ZVK gelegt, einen Nervenblock gestochen oder eine Drainage gelegt?

$\square$ Ja, nämlich:

$\square$ Nein

8 Kennen Sie den Zusammenhang zwischen Frequenz und Eindringtiefe beim Ultraschall?

$\square$ Ja, nämlich:

$\square$ Nein

9 Wissen Sie, in welchem Frequenzbereich der medizinisch genutzte Ultraschall liegt?

$\square$ Ja, nämlich:

Nein

10 Könnten Sie das Phänomen des Schallschattens erklären? $\square$ Ja, nämlich: 
Nein

\section{Bitte nach dem Experiment ausfüllen:}

11 Waren die Anleitungen verständlich? Allgemeine Einführung zur Studie

unverständlich gut verständlich

\begin{tabular}{|l|l|l|l|l|l|l|l|l|l|}
\hline 1 & 2 & 3 & 4 & 5 & 6 & 7 & 8 & 9 & 10 \\
\hline
\end{tabular}

B1: Punktion parallel zum Schallkopf, ohne Navi

\begin{tabular}{|l|l|l|l|l|l|l|l|l|l|}
\hline 1 & 2 & 3 & 4 & 5 & 6 & 7 & 8 & 9 & 10 \\
\hline
\end{tabular}

B2: Punktion rechtwinklig zum

Schallkopf, ohne Navi

\begin{tabular}{|l|l|l|l|l|l|l|l|l|l|}
\hline 1 & 2 & 3 & 4 & 5 & 6 & 7 & 8 & 9 & 10 \\
\hline
\end{tabular}

B3: Punktion parallel zum Schallkopf, mit Navi

\begin{tabular}{|l|l|l|l|l|l|l|l|l|l|}
\hline 1 & 2 & 3 & 4 & 5 & 6 & 7 & 8 & 9 & 10 \\
\hline
\end{tabular}

B4: Punktion rechtwinklig zum

Schallkopf, mit Navi

\begin{tabular}{|l|l|l|l|l|l|l|l|l|l|}
\hline 1 & 2 & 3 & 4 & 5 & 6 & 7 & 8 & 9 & 10 \\
\hline
\end{tabular}

12 Wie sicher fühlten Sie sich bei den einzelnen Methoden?

B1 Punktion parallel zum Schallkopf,

unsicher
\begin{tabular}{|l|l|l|l|l|l|l|l|l|l|}
\hline 1 & 2 & 3 & 4 & 5 & 6 & 7 & 8 & 9 & 10 \\
\hline
\end{tabular}
ohne Navi

B2 Punktion rechtwinklig zum

Schallkopf, ohne Navi

\begin{tabular}{|l|l|l|l|l|l|l|l|l|l|}
\hline 1 & 2 & 3 & 4 & 5 & 6 & 7 & 8 & 9 & 10 \\
\hline
\end{tabular}

B3 Punktion parallel zum Schallkopf,

\begin{tabular}{|l|l|l|l|l|l|l|l|l|l|}
\hline 1 & 2 & 3 & 4 & 5 & 6 & 7 & 8 & 9 & 10 \\
\hline
\end{tabular}
mit Navi 
B4 Punktion rechtwinklig zum

\begin{tabular}{|l|l|l|l|l|l|l|l|l|l|}
\hline 1 & 2 & 3 & 4 & 5 & 6 & 7 & 8 & 9 & 10 \\
\hline
\end{tabular}

Schallkopf, mit Navi

\section{Zum Beantworten der folgenden Fragen nehmen Sie bitte die Seite mit den Begriffserklärungen zu Hilfe.}

13 Die folgende Frage bezieht sich auf beide Bedingungen mit Navigation. Wenn Sie mit Navigation punktiert haben, worauf haben Sie am meisten geschaut?

Ultraschallbild (2D, konventionell)

sehr wenig
\begin{tabular}{|l|l|l|l|l|l|l|l|l|l|}
\hline 1 & 2 & 3 & 4 & 5 & 6 & 7 & 8 & 9 & 10 \\
\hline
\end{tabular}

Projektion der Nadel-Achse in das 2D-

\begin{tabular}{|l|l|l|l|l|l|l|l|l|l|}
\hline 1 & 2 & 3 & 4 & 5 & 6 & 7 & 8 & 9 & 10 \\
\hline
\end{tabular}

Ultraschallbild

3D-Modell mit schematischem

Schallkopf und geschätzter

\begin{tabular}{|l|l|l|l|l|l|l|l|l|l|}
\hline 1 & 2 & 3 & 4 & 5 & 6 & 7 & 8 & 9 & 10 \\
\hline
\end{tabular}

Nadelposition

Meine Hände, die Nadel und das

\begin{tabular}{|l|l|l|l|l|l|l|l|l|l|}
\hline 1 & 2 & 3 & 4 & 5 & 6 & 7 & 8 & 9 & 10 \\
\hline
\end{tabular}

Modell

Anderes:

\begin{tabular}{|l|l|l|l|l|l|l|l|l|l|}
\hline 1 & 2 & 3 & 4 & 5 & 6 & 7 & 8 & 9 & 10 \\
\hline
\end{tabular}

14 Wie intuitiv verständlich fanden Sie die folgenden einzelnen Teile der Darstellung?

schwer verständlich leicht verständlich

Projektion der Nadel-Achse in das 2DUltraschallbild

\begin{tabular}{|l|l|l|l|l|l|l|l|l|l|}
\hline 1 & 2 & 3 & 4 & 5 & 6 & 7 & 8 & 9 & 10 \\
\hline
\end{tabular}


Geschätzte Nadelposition im 2D-

\begin{tabular}{|l|l|l|l|l|l|l|l|l|l|}
\hline 1 & 2 & 3 & 4 & 5 & 6 & 7 & 8 & 9 & 10 \\
\hline
\end{tabular}

Ultraschallbild

3D-Modell mit schematischem

Schallkopf und geschätzter

\begin{tabular}{|l|l|l|l|l|l|l|l|l|l|}
\hline 1 & 2 & 3 & 4 & 5 & 6 & 7 & 8 & 9 & 10 \\
\hline
\end{tabular}

Nadelposition

Rechteck, das den voraussichtlichen Schnittpunkt zwischen Nadel und

\begin{tabular}{|l|l|l|l|l|l|l|l|l|l|}
\hline 1 & 2 & 3 & 4 & 5 & 6 & 7 & 8 & 9 & 10 \\
\hline
\end{tabular}

Ultraschallebene anzeigt

Anzeige, ob die Nadel mit dem

Schallkopf parallel ist

\begin{tabular}{|l|l|l|l|l|l|l|l|l|l|}
\hline 1 & 2 & 3 & 4 & 5 & 6 & 7 & 8 & 9 & 10 \\
\hline
\end{tabular}

Andere:

\begin{tabular}{|l|l|l|l|l|l|l|l|l|l|}
\hline 1 & 2 & 3 & 4 & 5 & 6 & 7 & 8 & 9 & 10 \\
\hline
\end{tabular}

\section{Bitte nach dem Experiment ausfüllen:}

15 Die folgende Frage bezieht sich nur auf die Punktion mit Navigation bei denen die Nadel in der Ultraschall-Ebene war (B3: parallel zum Schallkopf, mit Navi).

Wie hilfreich fanden Sie die einzelnen Teile der Darstellung?

Projektion der Nadel-Achse in das 2DUltraschallbild

unnötig
\begin{tabular}{|l|l|l|l|l|l|l|l|l|l|}
\hline 1 & 2 & 3 & 4 & 5 & 6 & 7 & 8 & 9 & 10 \\
\hline
\end{tabular}

Geschätzte Nadelposition im 2DUltraschallbild

\begin{tabular}{|l|l|l|l|l|l|l|l|l|l|}
\hline 1 & 2 & 3 & 4 & 5 & 6 & 7 & 8 & 9 & 10 \\
\hline
\end{tabular}

3D-Modell mit schematischem Schallkopf

\begin{tabular}{|l|l|l|l|l|l|l|l|l|l|}
\hline 1 & 2 & 3 & 4 & 5 & 6 & 7 & 8 & 9 & 10 \\
\hline
\end{tabular}
und geschätzter Nadelposition

Anzeige, ob die Nadel mit dem Schallkopf parallel ist

\begin{tabular}{|l|l|l|l|l|l|l|l|l|l|}
\hline 1 & 2 & 3 & 4 & 5 & 6 & 7 & 8 & 9 & 10 \\
\hline
\end{tabular}


Andere:

\begin{tabular}{|l|l|l|l|l|l|l|l|l|l|}
\hline 1 & 2 & 3 & 4 & 5 & 6 & 7 & 8 & 9 & 10 \\
\hline
\end{tabular}

16 Die folgende Frage bezieht sich nur auf die Punktion mit Navigation bei der die Nadel rechtwinklig zur Ultraschall-Ebene war (B4: rechtwinklig zum Schallkopf, mit Navi). Wie hilfreich fanden Sie die einzelnen Teile der Darstellung?

Projektion der Nadel-Achse in das 2DUltraschallbild

unnötig
\begin{tabular}{|l|l|l|l|l|l|l|l|l|l|}
\hline 1 & 2 & 3 & 4 & 5 & 6 & 7 & 8 & 9 & 10 \\
\hline
\end{tabular}

geschätzte Nadelposition im 2DUltraschallbild

\begin{tabular}{|l|l|l|l|l|l|l|l|l|l|}
\hline 1 & 2 & 3 & 4 & 5 & 6 & 7 & 8 & 9 & 10 \\
\hline
\end{tabular}

3D-Modell mit schematischem

Schallkopf

\begin{tabular}{|l|l|l|l|l|l|l|l|l|l|}
\hline 1 & 2 & 3 & 4 & 5 & 6 & 7 & 8 & 9 & 10 \\
\hline
\end{tabular}

und geschätzter Nadelposition

Rechteck, das den voraussichtlichen Schnittpunkt

\begin{tabular}{|l|l|l|l|l|l|l|l|l|l|}
\hline 1 & 2 & 3 & 4 & 5 & 6 & 7 & 8 & 9 & 10 \\
\hline
\end{tabular}
zwischen Nadel und Ultraschallebene anzeigt

Andere:

\begin{tabular}{|l|l|l|l|l|l|l|l|l|l|}
\hline 1 & 2 & 3 & 4 & 5 & 6 & 7 & 8 & 9 & 10 \\
\hline
\end{tabular}

17 Glauben Sie, dass das Nadel-Navigations-System die Sicherheit bei ultraschallgestützten Punktionen erhöht?

gar nicht
\begin{tabular}{|l|l|l|l|l|l|l|l|l|l|}
\hline 1 & 2 & 3 & 4 & 5 & 6 & 7 & 8 & 9 & 10 \\
\hline
\end{tabular}

18 Glauben Sie, dass das Nadel-Navigations-System die Geschwindigkeit bei ultraschallgestützten Punktionen erhöht?

gar nicht
\begin{tabular}{|l|l|l|l|l|l|l|l|l|l|}
\hline 1 & 2 & 3 & 4 & 5 & 6 & 7 & 8 & 9 & 10 \\
\hline
\end{tabular}

19 Was würden Sie an der Grafikdarstellung verbessern? 
Wie bewerten Sie die Organisation der Studie?

gut
\begin{tabular}{|l|l|l|l|l|l|l|l|l|l|}
\hline 1 & 2 & 3 & 4 & 5 & 6 & 7 & 8 & 9 & 10 \\
\hline
\end{tabular}

20 War die Zeit der Einzelversuche angemessen?

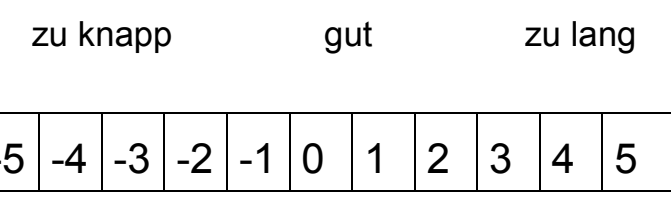

21 Eignet sich das Phantom zum Erlernen und Üben von Punktionstechniken?

schlecht 1 c gut
\begin{tabular}{|l|l|l|l|l|l|l|l|l|l|}
\hline 1 & 2 & 3 & 4 & 5 & 6 & 7 & 8 & 9 & 10 \\
\hline
\end{tabular}

22 Haben Sie das Gefühl, dass Ihnen die Teilnahme an der Studie persönlich genutzt hat?

$$
\begin{aligned}
& \text { wenig } \\
& \begin{array}{|l|l|l|l|l|l|l|l|l|l|}
\hline 1 & 2 & 3 & 4 & 5 & 6 & 7 & 8 & 9 & 10 \\
\hline
\end{array}
\end{aligned}
$$

23 Kommentare, Kritik, Verbesserungsvorschläge? 


\section{Begriffserklärung:}
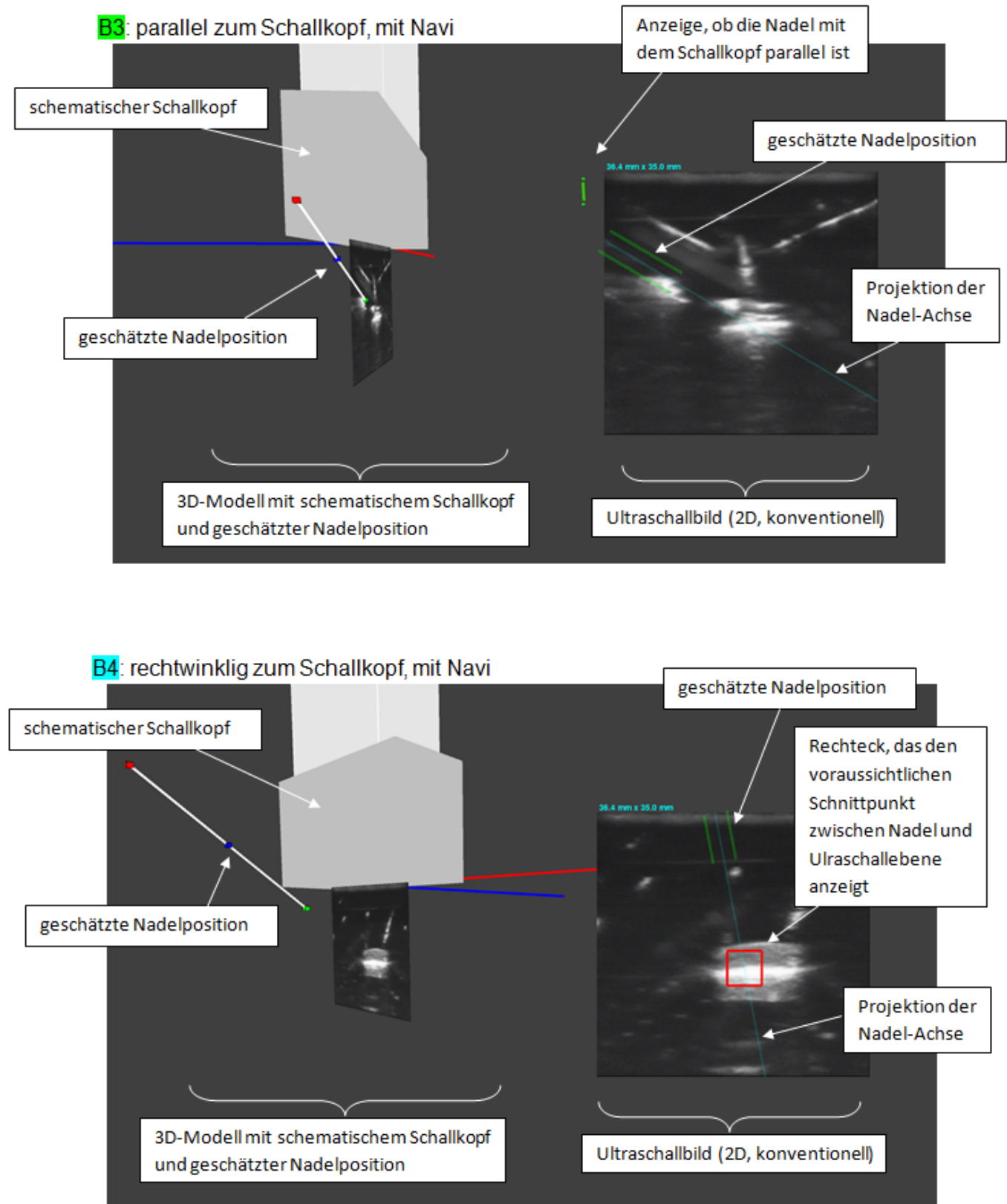

Vielen Dank für Ihre Teilnahme! 


\subsection{Danksagung}

Großer Dank gilt Prof. Dr. Guntinas-Lichius und Dr. Gerd Fabian Volk für die Begleitung und Betreuung meiner Arbeit. Ohne die Beharrlichkeit und Unterstützung von Dr. Volk wäre eine experimentelle Studie in diesem Rahmen nicht möglich gewesen.

Meiner Familie, die mich durch diese Zeit getragen und immer wieder ermutigt hat gilt besonderer Dank. Es tut gut diesen Rückhalt zu fühlen und sich darauf verlassen zu können.

Hannes, ohne Dich wäre diese Arbeit im Sande verlaufen. Die unzähligen Gespräche in den Bergen oder am Telefon haben mich stets ermutigt an mich und mein Tun zu glauben. Danke für deine unermüdliche Unterstützung. 


\subsection{Lebenslauf}

\subsubsection{Persönliches:}

Name: $\quad$ Verena Constanze Meiser

Geburtsdatum: $\quad$ 06.03.1989 in Schweinfurt

Anschrift: $\quad$ Kapellgasse 4

$\mathrm{CH}-8880$ Walenstadt

Telefon: $\quad 004915751862119$

Email: $\quad$ verena.c.meiser@googlemail.com

\subsubsection{Studium und Berufsausbildung:}

$04 / 2017$

$01 / 2016$

$11 / 2015$

$10 / 2014$

$05 / 2013$

Seit $05 / 2012$

$08 / 2011$

Seit $10 / 2008$
Oberassistenzärztin Innere Medizin, Spital Walenstadt, Schweiz Assistenzärztin für Innere Medizin, Spital Walenstadt, Schweiz Dritter Abschnitt der ärztlichen Prüfung; Zweiter Abschnitt der ärztlichen Prüfung;

Kongressstipendium für die 84. Jahresversammlung 2013 der Deutschen Gesellschaft für Hals-Nasen-Ohren-Heilkunde, Kopfund Hals-Chirurgie e.V.;

Doktorandin der Klinik und Poliklinik für Hals-, Nasen- und Ohrenheilkunde des Universitätsklinikums Jena;

Thema: Vergleich ultraschallgestützter Punktionstechniken am Ultraschallphantom;

Erster Abschnitt der ärztlichen Prüfung;

Studium der Humanmedizin an der Friedrich-Schiller-Universität Jena; Wahlfach: Klinik u. Anatomie der regionalen Leitungsbahnanästhesie;

09/1999 - 06/2008 Gymnasium Fridericianum Erlangen (Humanistisch) Leistungskurse: Deutsch, Musik

Abschluss: Allgemeine Hochschulreife;

\subsubsection{Praktische Erfahrungen und Zusatzqualifikationen:}

$07 / 2017$ Aufbaukurs Ultraschall Abdomen, SGUM, Mediweek Davos 
06/2016 Grundkurs Ultraschall Abdomen, SGUM, Kantonsspital Baden, Schweiz

04/2016 Weiterbildung interdisziplinäre Notfallmedizin für Assistenzärztinnen und - ärzte, Luzerner Kantonsspital, Schweiz

11/2008-09/2010 Ausbildung zum Rettungssanitäter an der Berufsfachschule des ASB Lauf

\subsubsection{Zusätzliche Tätigkeiten und Engagements:}

04/2010 - 09/2010 Vertrauensstudentin der Evangelischen Studentengemeinde Jena;

Seit $2004 \quad$ Mitarbeit und Leitung der Konfirmanden- und Jugendgruppen in Nürnberg-Boxdorf und Straubing (Versöhnungskirche);

\subsubsection{Besondere Auszeichnungen:}

Fünffache Preisträgerin im Wettbewerb „Jugend musiziert“ auf Regional- und Landesebene, Instrument Violoncello

Walenstadt, 18.09.2017 


\subsection{Ehrenwörtliche Erklärung}

Hiermit erkläre ich, dass mir die Promotionsordnung der Medizinischen Fakultät der Friedrich-Schiller-Universität bekannt ist,

ich die Dissertation selbst angefertigt habe und alle von mir benutzten Hilfsmittel, persönlichen Mitteilungen und Quellen in meiner Arbeit angegeben sind,

mich folgende Personen bei der Auswahl und Auswertung des Materials sowie bei der Herstellung des Manuskripts unterstützt haben:

Prof. Dr. med. Guntinas-Lichius, Dr. med. Gerd Fabian Volk, Dr. phil. Helene Kreysa

die Hilfe eines Promotionsberaters nicht in Anspruch genommen wurde und dass Dritte weder unmittelbar noch mittelbar geldwerte Leistungen von mir für Arbeiten erhalten haben, die im Zusammenhang mit dem Inhalt der vorgelegten Dissertation stehen,

dass ich die Dissertation noch nicht als Prüfungsarbeit für eine staatliche oder andere wissenschaftliche Prüfung eingereicht habe und

dass ich die gleiche, eine in wesentlichen Teilen ähnliche oder eine andere Abhandlung nicht bei einer anderen Hochschule als Dissertation eingereicht habe.

Walenstadt, 18.09.2017

Ort, Datum

Unterschrift des Verfassers 